\title{
The Earliest History of the Pechenegs
}

Very little is known about the origins of the Pechenegs. Those seeking to ascertain the time, place, and manner of their ethnogenesis have to rely on indirect data. Like most nomadic peoples, the Pechenegs first appear in the sources only after they attain a significant degree of political importance. No legendary version of their origo has survived, so researchers can offer only hypotheses about their origins. These hypotheses are often based on similarities between their ethnonym and that of another group found in the sources.

This was the case with Paul Pelliot's equating the Pechenegs with the Pei-ju (Beiru) people, who appear in the Book of Sui (Suí Shū), the official history of the Sui dynasty in China (581-618), written under the direction of Wei Zheng in 629-636. ${ }^{1}$ In it the Pei-ju are listed as part of the T'ie-lê (Tiele) confederation, which was based in the lands east of Fu-lin (Byzantium) and probably as far west as the Caspian Sea. ${ }^{2}$ While this identification has been recognized by some researchers, ${ }^{3}$ it is not universally accepted. ${ }^{4}$ In addition to philological doubts, historical premises also seem to speak against Pelliot's hypothesis. According to the information in the Book of Sui, the Pei-ju ought to be based in the Black Sea or Black Sea-Caspian steppe, and thus within Constantinople's sphere of interest. Therefore, if the Pechenegs were actually a tribe of the T'ie-lê confederation, they would most probably have been recorded in Byzantine historiography. However, we find no mention of them in the 7 th century.

The first written information generally regarded as reliable on the Pechenegs dates to the latter half of the 8th century: a diplomatic report prepared by five agents of the 'King of the Uyghurs' contains the following information: 'Northwest of them [i.e., the I-byil-kor tribe] is the Pecheneg [Be-ča-nag] tribe,

1 Pelliot 1949, 226.

2 The full text of the mention cited here, translated into German by Liu Mau-Tsai, reads as follows: 'Östlich von Fu-lin leben die En-k'ü, A-lan, Pei-ju, Kiu-li, Fu-wu, Hun und andere mit annähernd 20 ooo Mann.' Liu Mau-Tsai 1958, 128.

3 Kliashtornyi 1964, 117; 2003, 226-7; Pritsak 1975, 211.

4 P.B. Golden expresses doubts about this: 1990, 271; 1992, 264; 1995, 289 Friedrich Hirth identifies them with the Buljars or Bulgars, which seems more likely. Liu Mau-Tsai 1958, 569 (n. 663).

(C) ALEKSANDER PAROŃ AND INSTITUTE OF ARCHAEOLOGY AND ETHNOLOGY POLISH ACADEMY OF SCIENCES, 2021 | DOI:10.1163/9789004441095_005

This is an open access chapter distributed under the terms of the CC BY-NC-ND 4te kicenserer Paroń - 9789004441095 
they have five thousand warriors. They led the war against the Hor [Uyghurs]. ${ }^{5}$ The identification of the Pechenegs with the Be-ča-nag tribe does not arouse much controversy among experts on the subject, nor do scholars question the authenticity of this report, written sometime between 787 and $848 .^{6}$ However, further efforts to interpret the document have been controversial. Some researchers say that the Hor tribe mentioned in the document are none other than the Uyghurs. Such an identification leads to various hypotheses about the location of the Pecheneg nomads. According to some researchers, they were located north of Lake Balkhash or in the Upper Irtysh region. Based on battles mentioned in the report, the Pechenegs were said to have migrated westwards. ${ }^{7}$ It should be noted, however, that some scholars identify the Hors with the Oghuz (the Uzes in Byzantine sources), who are believed to have defeated the Pechenegs and driven them from their settlements on the lower Syr Darya River and the Aral Sea. ${ }^{8}$

This last hypothesis shares affinities with others derived from an etymological analysis of the name 'Kangar', used to refer to some Pecheneg tribes. Information about this group's existence is provided by Constantine VII Porphyrogenitus in his De administrando imperio, where he mentions them three times. The first occurrence coming near the end of Chapter 37:

The Pechenegs are also called 'Kangar', though not all of them, but only the folk of the three provinces of Iabdierti and Kouartzitzour and Chabouxingyla, for they are more valiant and noble than the rest: and that is what the title 'Kangar' signifies. ${ }^{9}$

In the next chapter, the learned emperor adds:

$[\ldots]$ the Pechenegs [...] were previously called 'Kangar' (for this 'Kangar' was a name signifying nobility and valour among them) [...]. And when battle was joined between the Turks and the Pechenegs who were at that

5 Bacot 1956, 143 (original), 147 (French translation). English translation: Zimonyi 2016, 68.

6 Tryjarski 1975a, 492.

7 Clauson 1957, 16; Tryjarski 1975a, 504; Senga 1992, 503-516. The supposed time of their migration westward was before the year 821. Senga 1992, 508-509.

8 Kliashtornyi 1964, 177-178; 2003, 227; Pritsak 1975, 215; Golden 199o, 271; 1995, 289.

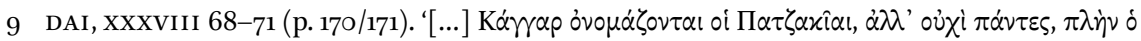

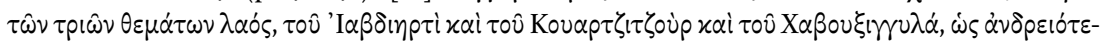

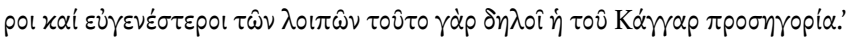


time called 'Kangar', the army of the Turks was defeated and split into two parts. ${ }^{10}$

The Byzantine monarch's mid-1oth-century text contains two very important pieces of information for interpreting the name 'Kangar'. The first is the particular qualities he assigns to the three Pecheneg tribes. These three tribes probably dominated over the whole ethnos. The second is the clear emphasis in the De administrando imperio on the long history of the name (Chapter 38 ). 'Kangar' is said to have been the name of an entire confederation of tribes before they began to be called the Be-ča-nag. Both the continuity in the ethnic tradition and the changes it underwent are important here, as the new ethnonym may be an indicator of major changes taking place in the group's political structure.

The information provided by Constantine viI Porphyrogenitus, and especially the information about the Pechenegs' former ethnonym, have fueled a great deal of speculation among scholars. It was believed, for example, that it would be possible to find the forebears of the Pechenegs among ethne with similar names. Such research sometimes focused less on the ethnos and more on the ethnonym. The given name 'Kangar' was known to the late $5^{\text {th- }}$ century Armenian author Lazar Parpetsi. In addition, it is found in two Syrian martyrologies from the latter half of the sixth century. ${ }^{11}$ On the basis of this information, Karoly Czeglédy concluded that the lands of the Kangar were located in the Caucusus between the Kura River and Lake Sevan, on the border between Albania and Iberia (Georgia). ${ }^{12}$ The Kangar ethnonym is associated with the word *kānk ('stone') from Tocharian A ('East Tocharian'). Based on this, Omeljan Pritsak concluded that the Kangar were originally inhabitants of Tashkent ('stone city') and the surrounding area. The Ukrainian researcher also links them to the people of K'ang-chü (Kangju), who were classified as Tocharians by Chinese sources from the Han Dynasty era (2nd century BCE). This tribal union was said to be comprised of two different, but complementary tribal groups. One consisted of nomads, the creators of great steppe empires (e.g., the great Yuezhi [Yüeh-chih], founders of the Kushan state), while the other were inhabitants of oasis towns where the primary means of support was

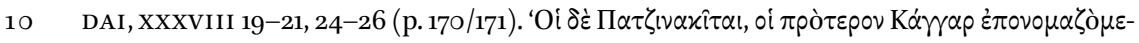

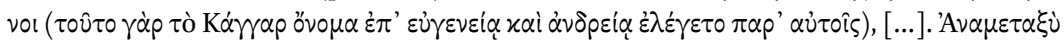

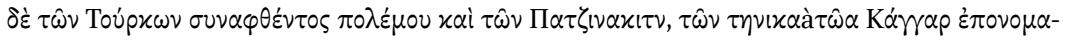

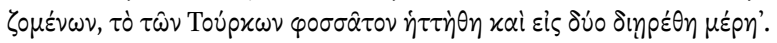

11 Czeglédy 1954, 14-45; 1954a, 65-66; 1956, 243-276.

12 Cf. Kliashtornyi 1964, 175-176; 2003, 225; Pritsak 1975, 211-212. 
trade. The two groups were connected not only by a shared language, but also by trade relations and shared common interests. Pritsak concludes that the Kangar were initially merchants and residents of towns along the Syr Darya River (mainly Tashkent). With time they formed an alliance with Turkic tribes and took their 'political name' from them. ${ }^{13}$

The name 'Kangar' has also been associated with the Kängäräs, who are mentioned in an inscription honouring Kül Tegin from the early 8th century. ${ }^{14}$ Based on its content, it has been established that around 713 the Kängäräs were attacked by the Türgäsh, who incited an uprising against the Orkhon Turks. Some researchers consider the Kängäräs to have been allies of this latter group and place their settlements on the Syr Darya and the Aral Sea. ${ }^{15}$ Additional evidence for this location was provided by Josef Marquart, a German researcher who noticed that the Syr Darya in its lower and middle sections was referred to as the Kängär or Känkär by medieval Muslim authors. The ethnonym 'Kengeres' should therefore be interpreted as Kängär-as, 'people of the Kangar River.' ${ }^{16}$ Marquardt also tried to connect the Pechenegs with the Kengeres based on another premise, one provided by al-Masudi, an Arab historian writing in the 1oth century. In one of his works, al-Masudi relates the reasons for the migration of four Turkic tribes, including the Pechenegs, and the Magyars to the west, as well as 'the wars and invasions that occurred between them and the Oghuz, Karluks and Kimäks on the Jurjān Sea [Aral Sea].' ${ }^{17}$ The events referred to here are usually dated to the gth century; however, there is a lack of agreement about a more detailed chronology..$^{18}$ For our purposes, of greatest importance is the fact that Marquart considered al-Masudi's relation to be confirmation of the Pechenegs' presence in the environs of the Aral Sea and Syr Darya. ${ }^{19}$ However, al-Masudi's account cannot be treated as evidence in support of this thesis. The fact that warfare was waged in the Aral Sea region does not automatically mean that any of the peoples involved had settlements nearby. Likewise, aspirations to extend control over an area of the steppe cannot automatically be equated with the expansion of an area of settlement. The history of the political organisms created by nomads provides many examples demonstrating the potential for a decoupling of these two phenomena. Moreover, it seems that al-Masudi could have referred to the Jurjān Sea

\footnotetext{
13 Pritsak 1975, 212-213.

14 Thomsen 1924, 152-153; Malov 1951, 32 (transcription of Old Turkish text), 41 (translation).

15 Marquart 1898, 10; 1914, 35, 99; Kliashtoryi 1964, 162-3; 2003, 211, 213.

16 Marquart 1914, 26; 1898, 10-11; Golden 1972, 58; 199o, 271-272; 1995, 289.

17 al-Mas'ūdī, Kitāb, s. 18o-181. Cf. Golden 1972, 58-59 (n. $\left.5^{2}\right)$.

18 Cf. below.

19 Cf. also Kliashtornyi 1964, 164-5, 177-179; 2003, 227-8.
} 
merely as a point of reference. The battles described could have taken place in its immediate vicinity or more distant from it, somewhere on the steppe of today's central Kazakhstan.

The ethnonym Kängäräs figured into Pritsak's hypothesis as well, but he proposed a different interpretation in which the term contains two separate elements. The first is the previously-mentioned Tocharian word *kānk-, while the latter has its source in the name of the Aorsi ('Aorsoi=*ãvrs->ārs$>$ ās'), an East-Iranian tribe. Since the first component was rendered in Turkic as a pre-syllabic word, the vocalism of the second component was governed by the principle of apophony (Umlaut). According to Pritsak, the ethnonym Kängäräs should therefore be interpreted as *Kängär As, meaning 'stone $\bar{A} s$ [people]', which he said indicated that around the eighth century they were associated with the Alani-Asi confederation. ${ }^{20}$

Pritsak also states that following the collapse of the Orkhon Turk (Tujue) empire (744), ethnic shifts in Central Asia forced the Pechenegs to migrate to the Transvolga region. By the mid-8th century, the Uyghurs had achieved hegemony on the Inner Asian steppe. In a punitive expedition following an earlier insurrection, their allies the Karluks attacked the Oghuz Turks, who lived in north-east Mongolia. The latter were forced to leave their settlements and migrate to environs of the upper Syr Darya and the Aral Sea, where their settlements neighboured those of the Pechenegs. It was here that the clashes mentioned in the 'Report of the Five Hors' are said to have taken place, forcing the migration of the Pechenegs. The Oghuz sought to wrest from the Pechenegs control of this area, which was a valuable region in terms of trade. The Pechenegs, whose nucleus was comprised of Kangar, who had inhabited oasis towns and engaged in the trade of goods for centuries, were defeated and forced to leave their settlements and relocate them on the steppe of today's western Kazakhstan, which led to a radical change in their lifestyle. From this time on, the Pechenegs would live as typical nomads. Pritsak dates these events to the early 9 th century. The next clash between these ethne is believed to have taken place around the year 830. This time the Pechenegs, having crossed the Volga, moved onto the Black Sea steppe. ${ }^{21}$

Peter B. Golden assumed a version of accidents very similar to those proposed by Pritsak. In his opinion, the Pechenegs were descendants of an earlier wave of Turkic peoples who led a pastoral way of life and settled around the Iranian cities of Transoxania (Mā warā' an-Nahr). The area was known to Chinese sources under the name K'ang-chü. An influx of additional Turkic groups

\footnotetext{
$20 \quad$ Pritsak 1975, 213.

21 Pritsak 1975, 214-216.
} 
began in the 6th century, leading to a gradual process of Turkification of the area's Iranian inhabitants. Also moving into the area were the Pechenegs, who Golden identifies with the Kängäräs people and places in the area of the town of Kängü Tarban on the Syr Darya. ${ }^{22}$ Conflicts with the Karluk, Kimek (Kimäk), and, above all, Oghuz peoples led to the forced exodus of the Pechenegs from this area. The works of the 11th-century Iranian writer al-Biruni contain valuable information relating to this period. ${ }^{23}$ Basing his claims on earlier sources, he writes that the Pechenegs inhabited the Aral Sea region, while in another work he states that their settlements neighboured those of the Karluks. Golden additionally refers to Oghuz folklore, in which the memory of wars with the It-Bäčänä (Pecheneg-Dogs) has been preserved. ${ }^{24}$ In a work by Abu-l-Gazi, a khan of the Khanate of Khiva who reigned in the 17th century, we find information about battles between one of the Oghuz tribes (Sal'or) and the Pechenegs. If these colourful and semi-legendary stories are based on real events, then they should be dated (according to most researchers) to the gth century. It is not possible to determine the time and place of these conflicts more precisely, though from Abu al-Gazi's account, it is clear that the Pechenegs were on the victorious side.

Based on this evidence, Golden concluded that the Pechenegs were driven from their lands on the Syr Darya due to ethnic displacements in the first third of the 9th century caused by wars fought between the Karluks and the Uyghurs - and later, the Kyrgyz (Kirghiz). This led to the collapse of the Uyghurs (840), hitherto the dominant force in the eastern part of the Great Steppe. According to Golden, the effects of these migrations were not limited only to Inner Asia. Waves of ethnic migration not only led to the appearance of the Oghuz, Kimaks and Karluks on the Syr Darya and forced the Pechenegs to flee to the west, but also led the Magyars to leave Bashkiria and move onto the Black Sea steppe (840-41). These events, he says, forced the Khazars to build an extensive system of fortifications of which Sarkel was only a part. They also contributed to the Byzantine Empire's reengagement along the northern shores of Pontos, as evidenced by the construction of not only the above-mentioned fortress, but also the city of Kherson. ${ }^{25}$

Golden's hypotheses deserves a closer, more critical look, as the Pechenegs' presence in the environs of the Aral Sea and the lower and middle Syr Darya

22 Golden thus follows the consensus among Russian scholars: Kliashtornyi 1964, 164-165; 2003, 228; Romashov 1999, 21.

23 Biruni, 95-6.

24 Abu-l-Gazi, 56, 71, 73-74. Cf. Zhirmunskii 1962, 181-187; Golden 1972, 58-59.

25 Golden 1972, 59-68. Cf. Zuckerman 1997, 214. 
has not been definitively confirmed. In spite of his laudable efforts to explain the causes of nomadic migrations and show their connection to events in the 9th century that involved directly or indirectly almost every significant political organism on the Great Steppe, the arguments Golden puts forward seem less than convincing. First, the chronological premises underlying his concept are not based on hard facts. It is difficult to link the construction of the Sarkel fortress (in the 83os) with the migrations that are said to have led to the collapse of the Uyghur state. Moreover, the reasons for the Khazar Khaganate's building the fortress are not entirely clear. They need not have been, or at least not only have been, motivated by a desire to hold back the Magyars or other peoples. Golden's identification of the Pecheneg Kangar, and of the Pechenegs themselves with the Orkhon Kängäräs, is even more questionable. In principle, the only argument for such an identification, apart from similarities in the two ethnonyms, is the proximity of the homelands of these peoples in the 8th century, a question that remains largely speculative. Likewise, the alleged link between the Kängäräs and the Alan-As confederation proposed by Pritsak has not gained wide acceptance. It is also difficult, as György Györffy has argued, to positively identify the Pecheneg as the Caucasian Kangar found in Armenian and Syrian sources. ${ }^{26}$ However, the most serious reservations concern the theory that the Pechenegs have their origins in an East Iranian ethnos. The problem here is not the idea that within one tribal union there would be two groups with different origins, because such phenomena certainly occurred. ${ }^{27}$ Rather, what is hard to imagine here is that, in accordance with the hypothesis presented above, the semi-nomadic or fully settled inhabitants of an oasis town would have so suddenly adopted a nomadic way of life and so quickly come to lead a steppe-based tribal organization. Sergei Kliashtornyi has noted a number of difficulties that would have resulted from such a rapid cultural change - one that would have required adapting to radically different natural conditions. ${ }^{28}$ This is how he explains the presence of the so-called yatak ['indolent'] social class among the Oghuz Turks, as testified by Mahmud alKashgari. This was the name applied to members of an ethnos who did not go to war or live a nomadic lifestyle. ${ }^{29}$ According to Kliashtornyi, the yatak were semi-nomadic Pechenegs, the inhabitants of oasis towns who were unable to adapt to life on the steppe.

26 Györffy 1978, 123-126; Kristó 1996, 140-141.

27 Cf. Wenskus 1961.

28 Kliashtornyi 1951, 61.

29 al-Kāšgarī III 11. Cited from: Zeki Validi Togan 1939, 146. 
However, this explanation is less than satisfactory. If we take into account the Kangar origins proposed by some scholars for the Pechenegs, in particular Pritsak, then we have to conclude that they were largely predestined to become yatak. Given this situation, it is hard to imagine that they could have led an entire people and, moreover, make claims to their noble origins and military valour. Claims to the complete Turkification of the Kangar also raises serious doubts. Among the relics of the Pecheneg language (though it is true that not much of it has survived), words of Turkic origin clearly dominate. Statements made about the Pechenegs by authors of their time confirm this fact. Anna Komnena states that the Pechenegs spoke the same language as the Cumans. ${ }^{30}$ Mahmud al-Kashgari, on the other hand, considers their language to be a corrupted form of Turkic. Most contemporary researchers also conclude that they spoke a Common Turkic language. ${ }^{31}$ A question then arises as to whether such a sudden and complete process of Turkification could have taken place in an ethnos whose elites would have been of foreign descent. This possibility cannot be ruled out, as the history of the Danube Bulgars and Varangians in Rus' seems to indicate. ${ }^{32}$ However, such an assimilation process is always a lengthy one and traces of former ethnic differences remain.

Finally, the above hypotheses only have relevance if the word 'kangar' is treated as a foreign word or ethnonym. Meanwhile, research has proven that its etymology can potentially be derived from Turco-Mongol languages. The word 'kangar' therefore could in fact correspond to the Turkic word qüngïr, meaning 'stubborn, firm, courageous, brave'. ${ }^{33}$ Such an interpretation would confirm Constantine VII Porphyrogenitus' information about the name's ennobling aspect. An interesting etymological analysis was presented by Karl H. Menges, who argued that 'kangar' could be derived from the word qan, which is considered an abbreviated version of khan or khagan. This would give it the following lexical structure: qan + noun suffix -gar, and, corresponding to the Turkic qangar, the meaning 'royal', 'ruling', or 'those close to the ruler'. Menges evokes an analogy with the Royal Scythians of Herodotus. ${ }^{34}$ It is known that this type of titular was used in reference to dominant elements in other Iranian tribal unions. Was the same true of the Turkic Pechenegs? This cannot be ruled out.

\footnotetext{
$30 \quad$ An.Kom., viII 5.6 (pp. 247-248).

31 Golden 1995, 290.

32 Halperin 2007, 84-98: Halperin provides interesting comments on the assimilation of the elites into an ethnic environment foreign to them. The process may have been quite lengthy due to deliberate resistance on the part of the ruling social group, since maintaining their political dominance depended on them preserving their distinct identity.

33 Moravcsik 1983a, 145.

34 Menges 1944-45, 270-271.
} 
Menges' interpretation is appealing, but, as the author himself has pointed out, it is only one of a number of possibilities.

In the light of current research, the Pechenegs' origins thus remain uncertain. They began to be noticed as an independent people by outside observers no earlier than the mid-8th century. At that time they were based somewhere on the steppe of today's eastern or central Kazakhstan (Aral Sea region). More detailed interpretations of extant sources would be merely hypothetical in nature, and any effort to reconcile them would by necessity entail arbitrary speculation. After their defeat by the Hors, the Pechenegs may have migrated from Lake Balkhash or the upper areas of the Irtysh River to the steppe north of the lower and middle Syr Darya. The choice of such a route can be justified based on both geographical and economic considerations, as the nomadic Pechenegs would have been naturally drawn to the rich oasis towns of Central Asia. Yet such an interpretation, though plausible, is little more than informed speculation. It is just as easy to assume that at the dawn of their history the Pechenegs were already residing on the Syr Darya, or, more likely, on the steppe stretching north of the river and the Aral Sea.

Their ethnogenesis is likely to have come after the break-up of the Western Turkic Khanate. At that time, no single Turkic tribe exercised hegemonic control over the Great Steppe. Up until the end of the $7^{\text {th }}$ century, this area belonged to China, which ruled it with the help of Turkic vassals. However, in 679 a large horde (orda) of Göktürks (Blue Turks) left the steppe of Ordos, travelled north and began to form what became the Göktürk Khanate. They were decidedly hostile to the Chinese empire, and their arrival was considered a moment of liberation by the inhabitants of the western zones of the Great Steppe. Constant threats to the northern boundary of the Middle Kingdom would limit its ability to interfere politically in the region. This state of affairs was further exacerbated the growing importance of Tibet, which beginning in the early 7 th century would become a dangerous enemy of China. ${ }^{35}$ It can thus be said that in the early 8th century the steppe between Dzungaria and the Volga region became a place of freedom for smaller ethne, unable to impose their rule on their neighbours, like the Khazars on the lower and middle Volga and the Black Sea steppe, or the Blue Turks in the eastern areas of the Great

35 The rivalry between China and Tibet started during the reign of King Namri (570-620). It reached its apex, however, in the second half of the 7 th century. Although China ultimately triumphed, the more than century-long conflict considerably weakened the position of the Middle Kingdom on the Great Steppe. Gumilev 1993, 250-258; Hoffman 199o, $376-382$. 
Steppe. ${ }^{36}$ It was during this period that the Pechenegs may have emerged as an independent political entity.

Analysis of their ethnonym yields some interesting facts. The word 'pecheneg' is generally assumed to mean 'wife's sister's husband, brother-in-law'. 37 The term is thus said to prove that the Pechenegs, and in particular, their elites, belonged to the 'brother-in-law' clans, which occupied a high position within the imperial political structures of the Great Steppe (Tur. el/il) and had close ties to the ruling clan. ${ }^{38}$ Pritsak sees a clear link between the Pechenegs and the Ashina dynasty, which ruled the Turkic Khaganates $\left(55^{2-744)}\right)^{39}$ Such an interpretation is not unfounded, but it poses questions about the branch of the Ashina clan with which the Pechenegs elite is said to have had such close relations. One is also tempted to associate them with the Göktürk dynasty, which in the last decades of the $7^{\text {th }}$ century began rebuilding the Eastern Khanate. If the Hor mentioned in the above-mentioned diplomatic report were in fact Uyghurs, this would also help explain their hostile relations with the Pechenegs. As the Göktürks' conquerors and successors, they would have aroused the ire of that group's close allies. However, we know that the Hors can also be identified with the Oghuz Turks. In this case, the Be-ča-nag would have enjoyed close contacts with the dynasties of the declining Western Turkic Khanate. One conclusion can be positively drawn from these suppositions: in the 8th century the Pechenegs may have already enjoyed significant political importance in the lands between the Transvolga region and Dzhungaria.

\subsection{Pechenegs on the Transvolgan Steppe}

More detailed information about the Pechenegs exists concerning the period when they lived on the Transvolgan Steppe. It is difficult to say exactly when they arrived in this area, likewise with the cause of their migration. However, it can be cautiously assumed that it took place in the second third of the

$36 \quad$ A state of relative freedom and rivalry among smaller ethne on the western stretches of the Great Steppe would continue for another few centuries. In 8th and 9th centuries, the Karluks, who originally inhabited the area between the western part of the Altai Mountains and the Irtysh River, had their greatest period of significance. Their dominance was brought to an end by the Samanids in late 9th century, which led to a series of ethnic shifts. Kałużyński 1986, 61-62; Golden 199oa, 348-354; Tryjarski 1975a, 5 O4.

Pritsak 1975, 211; Schamiloglu 1984, 215-222; Bazin 1986, 73. A different opinion was held by Doerfer 1965, 233 .

38 Pritsak 1952, 52, 79; 1988, 749-78o.

39 Pritsak 1975, 211. 
${ }^{\text {th }}$ century, ${ }^{40}$ perhaps under pressure from other Turkic tribes mentioned in al-Masudi's account. ${ }^{41}$ However, it cannot be ruled out that the nomads were attracted by the area's proximity to the affluent Khazar Khaganate and the desire to profit from the dynamic expansion of trade along the Volga River.

More detailed information on the location of the Pechenegs' nomadic settlements can be found in the writings of al-Gardīzī, al-Bakrī, and al-Marwazī, i.e., Muslim authors whose works provide information from a lost 9 th-century source, known as The Anonymous Account. ${ }^{42}$ The first two of these authors state that after leaving Jurjāniyyah (i.e., Urgench), a city located in the Khwārazm region $^{43}$ and covering a distance of 12 parasangs, you reached what was called Khwārazm Mountain. ${ }^{44}$ This was probably one of the peaks of the Ustyurt Plateau. ${ }^{45}$ Gardīzī adds that once you reached Khwārazm Lake, you continued along its shore, keeping it to your right side. The author here is probably talking about the Aral Sea, and thus confirming the identification of the abovementioned elevation. Gardīzi also states that during the journey, you passed through a waterless steppe (Ustyurt Plateau), and on the ninth day of your travel you would reach a spring where there were numerous animals. On the seventeenth day of the journey, you finally reach the areas controlled by the Pechenegs. ${ }^{46}$ We can therefore assume, on the basis of Gardīzi's report, supplemented by information from al-Bakrī, that the Pechenegs' encampments were located beyond the Ustyurt Plateau, and seven days' travel north-west of them. The last conclusion is based on the following premise. If the Pechenegs inhabited areas located due north of Ustyurt, then their nomadic settlements would be located on the southern slopes of the Urals. However, in al-Bakrī we read:

40 Łowmiański 1973, 61-62; Lewicki 1977, 12; Gumilev 1993, 375. Łowmiański claimed that the Pechenegs' camps had already reached the lower Volga in the mid-8th century. A similar opinion is held by A. Róna-Tas $(1999,235)$. He believes that the Pechenegs were already present on the Yaik and Volga rivers at the time when the 'Report of the 5 Hors' was being prepared, and that this is where their original homeland should be located.

41 Cf. footnote 17 above.

42 Cf. the introductory chapter of the present book.

43 It is usually identified as present-day Kunja Urgenč, a town located on the lower Amu Darya, about $30 \mathrm{~km}$ from present-day Nukus. Göckenjan, Zimonyi 2001, 163 (n. 384).

44 Gardīzī: Göckenjan, Zimonyi 20o1, 162-164; Martinez 1982, 151. Bakrī: Kunik, Rozen 1878, 58-9; Göckenjan, Zimonyi 2001, 221. Zachoder 1967, 71.

45 For more on the identification of Khwarezmian Mountain: Minorsky 1937, 314 (n. 1); Göckenjan, Zimonyi 2001, 163 (n. 385). On the identification of other geographical terms: Tryjarski 1975a, 507.

46 A different opinion was held by V. Bartol'd (1897, 119-120), who, based on data from Gardīzī's account, initially estimated that Urgench was a 27-day journey from the Pecheneg lands. In a later work, he revised his estimates and shortened the distance to a journey of 17 days. Bartol'd 1963, 82o. Cf. Zakhoder 1967, 71 . 
'The country of the Pechenegs is completely flat. There is neither mountain there nor stronghold to take refuge in it. 47

We can thus tentatively posit that in all probability they inhabited the steppe between the Volga and the Emba River. ${ }^{48}$ More precise information on the homelands of the Pechenegs in the 9th century can be found in Constantine VII Porphyrogenitus' De administrando imperio. In the chapter discussing events connected with the Pechenegs' leaving the Volga region, it states:

Originally, the Pechenegs had their dwelling on the river Atil, and likewise on the river Geïch, having common frontiers with the Chazars and the so-called Uzes. ${ }^{49}$

On the basis of this reference, some researchers assumed that the territory of the Pechenegs lay between the Volga and the Ural rivers. ${ }^{50}$ Such an interpretation is not entirely convincing. While the fact that the Pechenegs' nomadic settlements (due to their proximity to the Khazar's trading empire) could not have been located on the right bank of the Volga is undisputable, we cannot talk about their border with the Ohguz (Uzes) with a similar level of certainty. This is definitely not offered by Constantine viI Porphyrogenitus' claim that

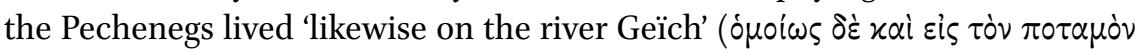
$\Gamma \varepsilon \eta \dot{\chi} \chi$ ). The thesis that they lived on the right side of the river is only one possible interpretation; the Pechenegs just as easily could have ruled over both banks of the river. It is worth considering this possibility, especially if we take into account the evidence we have indicating such was the case. Ahmed ibn Fadlan, a member of the embassy of Abbasid Caliph al-Muqtadir to the ruler of the Volga-Kama Bulgars, noted during a journey in the spring of 922 the existence of impoverished Pechenegs in the Transvolga. ${ }^{51}$ The decidedly antiKhazar nature of his mission forced ibn Fadlan to take a route far from the Khazars' lands. Therefore, not only did he not cross the Volga, but in the lower

47 Bakrī: Kunik, Rozen 1878, 59; Zakhoder 1967, 75; Göckenjan, Zimonyi 2001, 222. English translation Zimonyi 2013, 102 (note 10).

48 A similar location, but without supporting evidence, was given by Tadeusz Lewicki (1970, $85^{-86)}$.

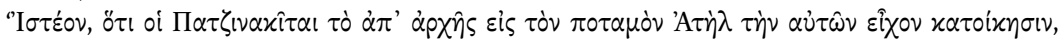

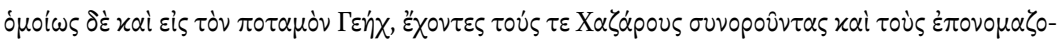

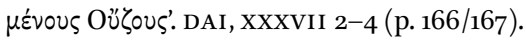

$5^{\circ}$ Such an interpretation was adopted by Macartney 1929, 343. Likewise: S.A. Pletneva 1958, 154, fig. 1; Varady 1982, 26.

ibn Fadlan: ibn Fadlan, 212; Zeki Validi Togan 1939, 33; Kovalevskii 1956, 13o; Frye 2005, 42. 
and middle course of the river, he steered clear of the valley of the Volga in general. A similar thesis, combined with information that these Pechenegs inhabited an area by some 'non-flowing' lake, gave reason to locate them in the area of Shalkar Lake near Oral (Rus. Ural'sk). ${ }^{52}$ It is especially important to remember that this place was located on the left bank of the Ural river, not far from the area where it turns sharply to the south and directs its course towards the Caspian Sea. Of course, it can be suggested that between the moment when the main part of the Pechenegs left the Volga region and Ahmed ibn Fadlan wrote his notes, ethnic shifts occurred which ultimately forced weaker tribal groups to cross the Yaik (Ural) River. It seems unlikely, however, that such circumstances existed.

The Pechenegs' nomadic settlements could therefore also have extended east of the Ural River. Such an assumption is further reinforced by the mention in Arab sources from the al-Jayhāni tradition that the Pechenegs' territory stretched over the equivalent of 30 days' travel. ${ }^{53}$ This is a huge area. Even if we believe that the ratio proposed by Tadeusz Lewicki for converting travel days into distances measured in kilometres is exaggerated, ${ }^{54}$ it still seems unlikely that such a large territory would be located between the Volga and the Yaik-Ural. This is all the more difficult to believe when we take into account the fact that after losing in their rivalry with the Khazars and Oghuz (Uzes), and after experiencing demographic losses that are difficult to estimate, but no less important, the Pechenegs still managed to control large nomadic settlements on the Black Sea steppe, stretching, according to Constantine VII Porphyrogenitus, from the Khazar's fortress in Sarkel on the Don to the Lower Danube.

Thus, if the Pechenegs' encampments were also located on the left bank of the Ural, how far east could they have stretched? This question is extremely difficult to answer. However, it seems that given the nomads' attachment to their natural environment, such as the steppe and forest steppe, it can be assumed that the pastures of the Pechenegs were limited by the south-eastern slopes of the Urals and their extensions, the Mugodzhar Hills. ${ }^{55}$

\footnotetext{
$5^{2}$ ibn Fadlan: Zeki Validi Togan 1939, 33 (n. 5); Kovalevskii 1956, 192 (n. 308). Tryjarski 1975a, 513 .

53 Gardīzī: Göckenjan, Zimonyi 20o1, 164; Martinez 1982, 151. Bakrī: Kunik, Rozen 1878, 221. Marwazī: Minorsky 1942, 32-33; Göckenjan, Zimonyi 2001, 25o. Zakhoder 1967, 71.

54 T. Lewicki estimates that at an average speed, caravans travelled about 30 kilometers per day in this area. This means that the Pechenegs' encampments stretched over an area of 900 kilometers in both width and length. Lewicki 1977, 67 . 
This series of uncertainties also includes the problem of the peoples neighbouring the Pechenegs. According to Muslim accounts, their neighbours included the Khazars, Oghuz, Kipchaks, and Slavs (as-Sakaliba, Saqlab). The first two ethne have already been mentioned in the discussion of the accounts of Constantine VII Porphyrogenitus, who considered them to be one of the Pechenegs' neighbours at the end of the 9th century. ${ }^{56}$ Islamic writers differ about the direction in which these two ethne bordered the Pechenegs. According to al-Bakrī, the Khazars inhabited areas south of the Pechenegs, while al-Marwazī and al-Gardīzì place them to the southwest. The latter version is probably closer to the truth. In the case of the Oghuz (Uzes), there is agreement between al-Bakrī and al-Marwazī, who both say they lived on the steppe to the east of the Pechenegs. Al-Gardīzi makes no mention of them. The Kipchaks, also referred to as the Cumans or in Slavic as the Polovtsy, were said to occupy areas either to the east (al-Gardīzī) or north (al-Marwazī, al-Bakrī) of the Pechenegs. ${ }^{57} \mathrm{Al}-$ Gardīzìs version should be completely rejected, as he seems to have mistaken the Kipchaks for the Oghuz, and hence, the lack of information about the group in his writings. However, the information provided by the other two writers also needs to be corrected. Since we know that in the latter half of the gth century, the Kipchaks had nomadic settlements in the forest-steppe areas between the Irtysh and Tobol Rivers, ${ }^{58}$ their westernmost borders could have reached at most to the southern slopes of the Urals, and this is most probably the area where their lands bordered those of the Pechenegs. Therefore, the border between these two peoples ran northeast.

However, the greatest controversy seems to concern the Slavs in their environs. Although there is a consensus among Arab authors that Slavs occupied the territories west of the Pechenegs' encampments, the situation is less clear in relation to the Transvolga. As a result, some researchers are inclined to assume that these references are to the Volga-Kama Bulgars. The basis for a similar revision is that Ahmed ibn Fadlan, who lived among the Bulgars, called them as-Saqaliba, a name previously reserved for Slavs. ${ }^{99}$ However, this is

56 DAI, XXXVII 2-4 (p. 167/168).

57 Gardīzī: Göckenjan, Zimonyi 20o1, 164; Martinez 1982, 151. Bakrī: Kunik, Rozen 1878, 59; Göckenjan, Zimonyi 2001, 221. Marwazī: Minorsky 1942, 32-33; Göckenjan, Zimonyi 2001, 25o. Zakhoder 1967, 72-73.

58 Gumilow 1973, 82; Kumekov 1972, 56-7.

59 Tryjarski 1975a, 507 (n. 98). The ethnonym Șaqlab or Șaqāliba is found relatively often in Arabic texts and may be understood more generally as a nomen collectivum for the peoples inhabiting the forests and forest steppe zones of the lower and middle Volga River. Cf. Marquart 1903, 466f.; Zimonyi 199o, 149-150; Nazmi 1998, 73-113; Göckenjan, Zimonyi 2001, 165 (n. 39o). 
not the only possible revision. The British scholar Carlile Aylmer Macartney assumes these references are to the Burtas. ${ }^{60} \mathrm{~A}$ number of important pieces of information about them can be found in the writings of ibn Rusta. He writes, for example, that:

The lands of the Burdās (Burtās) are located between the lands of the Khazars and those of the Bulkār (Bulghār). They are fifteen days' march from the land of the Khazars. They obey the King of the Khazars and supply him with 10,00o horsemen. [...] Their lands are vast and they live in forests. They periodically raid the territories of the Bulkār and the Pečeneg. They are valiant and brave. [...] Their territory is seventeen days' march in length and breadth.

And further:

The Bulkār (Bulghār) border the lands of the Burdās (Burtās). They are camped on the bank of a river that flows into the Khazar Sea (Caspian), which is called the Itil (Volga). They live between the Khazars and the Saqāliba. ${ }^{61}$

The Bulkār who appear in ibn Rusta's account are Kama-Volga Bulgars. It is possible to situate the Burtas more precisely thanks to the work of T. Lewicki, who used information from ibn Rusta's writings and al-Iștahrìs itinerarium to determine the location of the southern border of their territory, which lay in the area of today's city of Saratov. His determinations are supported by a description of the Burtas' land as being in close range of forests and foreststeppe. We know that today the transition zone between the steppe and the forest-steppe stretches runs along the line of latitude where Saratov is found. The northern boundary of their territory, according to T. Lewicki's findings, was located in the area of today's Kuibyshev; in the east it was supposed to reach as far as the Volga. ${ }^{62}$ Taking into account the arguments given to support the location presented above, it must be admitted that C.A. Macartney's proposal rests on a stronger body of sources.

6o Macartney 1968, 26. The author assumes that mentions of the Slavs, rather than the Burtās, among the Pechenegs' neighbours was the result of a revision made by later editors.

61 Rusta: ibn Rusta, 29, 31; Göckenjan, Zimonyi 2001, 56, 57. English translation: Lunde, Stone 2012, 118, 120.

62 Lewicki 1977, 66-68; Zakhoder 1962, 230-238. 
The information provided by ibn Rusta allows us to speculate about the existence of some type of neighbourly relations between the Pechenegs and the Magyars when both tribes were still in the Volga region. We read in his work that:

Between the country of the Pečenegs and Iskil (Askel), which belongs to the Bulkār (Bulghār), lies the first of the Magyar frontiers. ${ }^{63}$

It is not easy to find a convincing interpretation of this information. It seems worth considering that before their arrival on the Black Sea steppe, the Magyar tribes could have inhabited an area of the Volga region in close proximity to the Pechenegs. Archaeological discoveries from the vicinity of the town of Ufa and the valley of the Belaia River, as well as to the south, in the lower reaches of the Kama, seem to confirm the assumption that these regions could have been inhabited by Magyars from the eighth century to the first half of the ninth century. ${ }^{64}$ Therefore, ibn Rusta's account would not seem to be an incomprehensible phantasmagoria, an issue that will be of particular importance when considering the later relations between these two peoples. At this point, it can only be stated that they could have lived adjacent to each other in the vicinity of the upper reaches of the Belaia River.

To sum up, it can be stated that the neighbours of the Pechenegs were: to the north and north-east, the Kipchaks and perhaps until their migration to the Black Sea steppe the Magyars, to the south-west and west the Khazars and the Burtas, and to the east, in the region of the Mugodzhar Hills, the Oghuz (Uzes).

A separate problem is the issue of the relations between the Pechenegs and their neighbours. If we believe Muslim authors, they were as bad as possible.

63 Rusta: ibn Rusta, 33; Göckenjan, Zimonyi 2001, 64-66. English translation: Lunde, Stone 2012, 122.

64 Dąbrowska 1979, 156-157; Fodor 1982, 210-217. Such an interpretation raises objections among many scholars. Marquart (1903, 515) deemed Ibn Rusta's account be a form of scholarly mystification. The Arabic writer supposedly associated Magyars with the Bashkirs, who in his day inhabited the northern Transvolga (present-day Ufa), based on similarities in their ethnonyms. This opinion was shared by Zimonyi 1990, 150-152. Kristó $(1996,105,170)$ considered Ibn Rusta's data trustworthy, but he applied it to the second half of the gth century, when Hungarians had already arrived on the Black Sea steppe. This prompted him to search for some kind of land passage that would connect the Transvolga region with the Magyars' encampments on the Black Sea, which at the same time, would have allowed them to establish contacts with the Pechenegs. This hypothesis seems rather artificial and unconvincing. Cf. Göckenjan, Zimonyi 2001, 66-7 (n. 80); Zimonyi 2014, 123-163; 2016, 82; Spinei 2003, 39-40. 
Al-Marwazī writes: 'These peoples [the Khazars, Kipchaks, Uzes, and most likely the Burtas - A.P.] all raid the Pechenegs, who [likewise] raid them. ${ }^{65}$ The same is stated by al-Bakrī. Al-Gardizì adds: 'All these peoples [...] they abduct them [Pechenegs - A.P.] into slavery and sell as slaves [...].66 However, such a state of permanent armed conflict and military oppression contrasts with the Pechenegs' wealth, to which all of the writers above testify. They are said to have possessed vast herds, large quantities of gold and silver, and expensive dishes and household appliances. ${ }^{67}$ How can we explain this contradiction? First of all, the Pechenegs were probably one of the strongest tribal unions in the Volga region. An apparent measure of their demographic, and therefore political potential was the huge size of the territory they occupied. ${ }^{68}$ No wonder, then, that they were probably able to effectively fend off their hostile neighbours. ${ }^{69}$ We must also take into account the possibility that although conflicts on the Eurasian steppe were quite common, they probably differed in intensity. We should remember that the Pechenegs, who were bordered to the west by the Khazars and their vassals, also lived alongside the major trade route the ran along the Volga. They also had direct contact with the rich Khazar Empire, which may have led to a desire to participate in their trading activities, or, in the absence of such opportunities, to carry out regular looting raids. We should therefore look to the west for the front lines of their battles with their neighbours; this is all the more so given that the Khazars might have seen them as a serious threat to their interests. The main objective of the Khaganate rulers was to create the best possible conditions for the flourishing of trade, from which they earned significant profits. Instability in the area of trade routes caused by the emergence of a difficult neighbour would have greatly limited their proper functioning. Limiting the Pechenegs' aggression or eliminating competition from them posed a very important task for the Khazar elites. This

65 Marwazī: Minorsky 1942, 33; Göckenjan, Zimonyi 20o1, 25 o.

66 Bakrī: Kunik, Rozen 1878, 59 (scholars interpret this text somewhat differently and have concluded that the Pechenegs traded with all their neighbours); Zachoder 1967, 72-3 (this includes other possible interpretations of the Arabic text); Göckenjan, Zimonyi 2001, 2212. Gardīzī: Zakhoder 1967, 73; Göckenjan, Zimonyi 2001, 164-5; Martinez 1982, 151 (considerably different interpretation of Gardīzì's passage: '[The Pechenegs] incite all these people[s] to raid [one another], and so they go marauding for the Pecheneg and taking captives and sell /these/').

67 Bakrī: Kunik, Rozen 1878, 59; Göckenjan, Zimonyi 2oo1, 222. Gardīzī: Göckenjan, Zimonyi 2001, 164-5; Martinez 1982, 152. Marwazī: Minorsky 1942, 33; Göckenjan, Zimonyi 20o1, 25o. Zakhoder 1967, 73-74.

68 Cf. Zimonyi 2013, 297.

69 István Zimonyi $(2013,298)$ interprets information about the Pechenegs fighting with neighbouring peoples as the evidence of their political independence. 
was probably the purpose of the systematic penal expeditions they carried out, which we read about in ibn Rusta's book:

Their king [the Khazars - A.P.], the $\bar{s} h \bar{a}$ imposes a levy of cavalry on the people of power and wealth, in accordance with their wealth and means. They raid Pečenegs every year. The $\bar{s} h \bar{a}$ leads the expedition himself, going with his men on raids. ${ }^{70}$

As mentioned, ${ }^{71}$ the Khazars had achieved hegemony on both the Black Sea steppe and the Volga region, and were thus capable of forming a coalition to keep in check the aggressive intentions of the Pechenegs. Its allies probably included the Burtas, an ethnos dependent on the Khazars; the Volga-Kama Bulgars were in a similar position of dependence until the early 1oth century, so it is possible that they also took part in battles on the side of their overlords. However, it is not entirely impossible that among the primary motives for these expeditions were the abductions mentioned by Gardizī. After all, as an object of trade slaves were a potential source of income, as the Khazars knew very well. The Pechenegs' chances of gaining an upper hand on their rival grew due to an internal crisis the khaganate suffered in the mid-gth century that resulted in a civil war. We do not know much about this conflict, apart from the fact that it may have been caused by dissatisfaction among some circles of the tribal aristocracy following the introduction of political and religious reforms. ${ }^{72}$ Ultimately, a group of three tribes known as the Kabars (Kabaroi) broke away from the Khazars and joined the Magyar tribal confederacy. ${ }^{73}$ For our purposes, most important was the fact that this conflict led to a temporary weakening of the Khazar state, giving the Pechenegs greater freedom of action. The forced migration of the Magyars to the Black Sea steppe was probably an earlier consequence of the Pechenegs' military actions, an issue we will return to in the last part of this chapter. The Pechenegs almost certainly became more active on the Volga trade route, as the Khazars' temporary weakness provided them with better conditions for successful plunder, which became one of the sources of the wealth mentioned by Arab writers. Of course, this may also have been derived from trade with the caravans passing through their territories, but the peripheral location of the Pechenegs, as well as their universally

70 Rusta: ibn Rusta, 29; Göckenjan, Zimonyi 2001, 54. English translation: Lunde, Stone 2012, 117 .

71 Cf. Chapter 2 of the present book.

72 Artamonov 1962, 324-334; Nagrodzka-Majchrzyk 1975, 400.

73 DAI, XXXIX; XL $3-7$ (p. 174/175). 


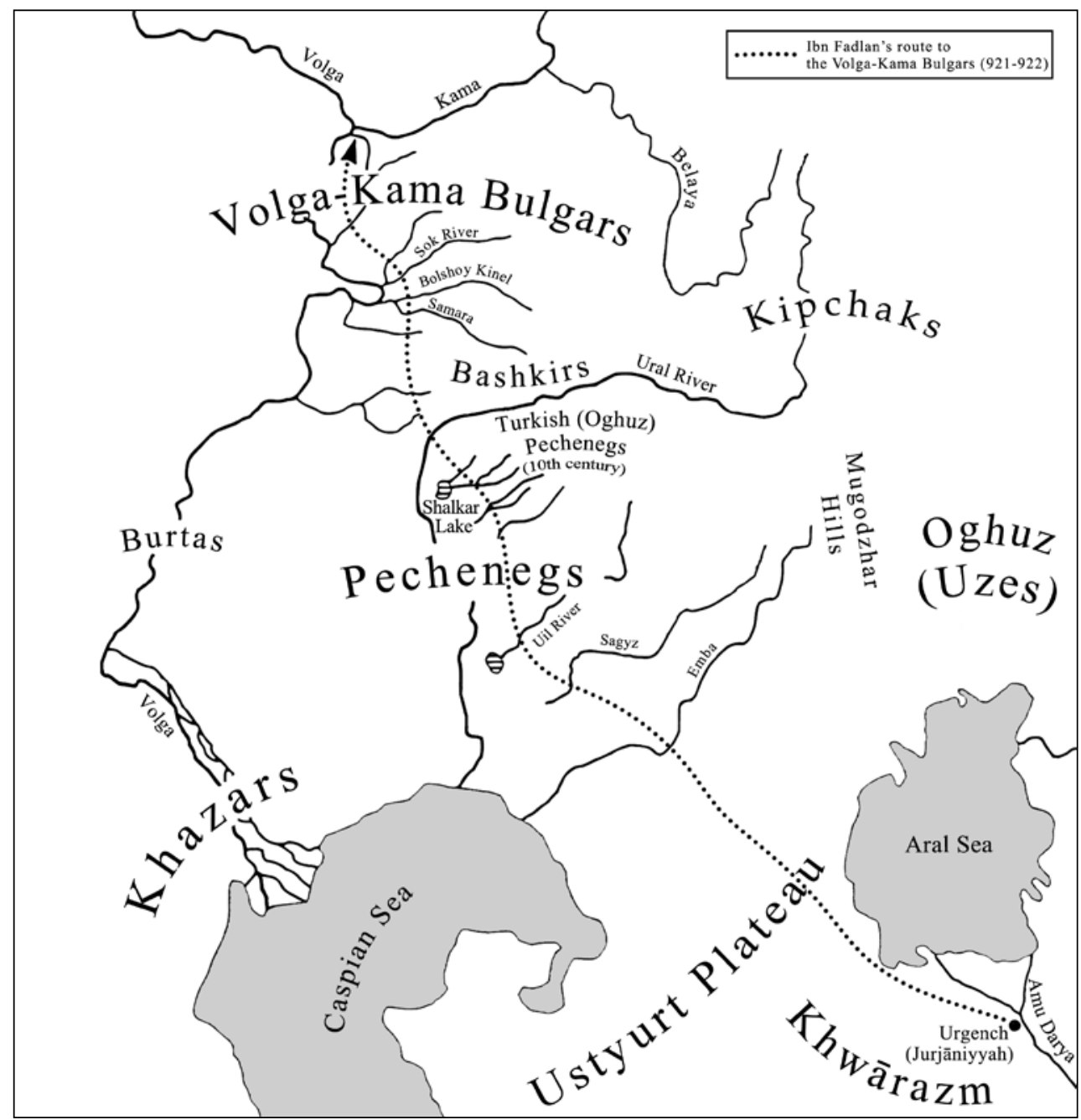

noted warlike character, probably limited the possibilities for such types of exchange.

The arguments presented above, however, do not exclude the possibility of minor conflicts also playing out on the eastern border of the Pechenegs' nomadic settlements. It seems, however, that the rich Khazar Empire and the trade routes running through it constituted a particularly attractive area for expansion, while victories over the Pechenegs' eastern and north-eastern neighbours, who had attained a similar level of development, could not supply the Pechenegs with equally valuable loot. 


\subsection{The Pechenegs' Wars with Magyars. Migration to the Black Sea Steppe}

A similar state of affairs lasted until the end of the gth century. The Khazar Khaganate was supposed to effect the removal of these troublesome neighbours from the Volga region with the help of a strong ally. Quite unexpectedly, this turned out to be the Oghuz (Uzes). Very little is known about the specific circumstances leading to the creation of this alliance directed against the Pechenegs. We owe what basic information we have about it to Constantine VII Porphyrogenitus. We read in Chapter 37 of De administrando imperio:

But fifty years ago the so-called Uzes made common cause with Chazars and joined battle with the Pechenegs and prevailed over them and expelled them from their country, which the so-called Uzes have occupied till this day. ${ }^{74}$

In the next chapter, the learned emperor adds:

Now, the Pechenegs who were previously called 'Kangar' [...], these, then, stirred up war against the Chazars and, being defeated, were forced to quit their own land and to settle in that of the Turks [i.e., Magyars - A.P.] ${ }^{75}$

The first fragment seems to indicate that the political and military initiative was on the Oghuz side. It is therefore important to determine what led to an increase in the activity of this ethnos. This phenomenon is all the more puzzling because, despite their constant conflicts with the Pechenegs, as recounted in Arab sources, it was not until the end of the gth century that the Oghuz mustered up the resources to deliver such a powerful blow to their western neighbours. The motivation for such a fierce fight should most probably be sought in the political situation that emerged on the western stretches of the Great Steppe after the creation of a Sunni empire by the Samanids. This empire, which originally inhabited Transoxania, managed to conquer much larger territories during a rapid expansion in the late 9th century. In 893, the Samanid

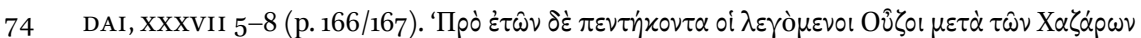

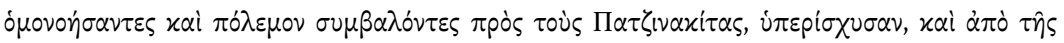

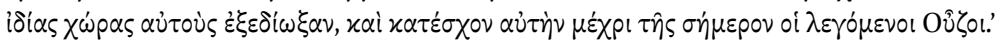

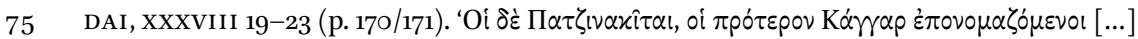

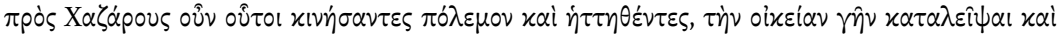

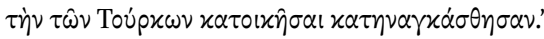


ruler Ismail ibn Ahmed defeated a Turkic tribe, most probably the Karluks, who lived in Semirechie (Zhetysu), forcing them to migrate west, thus triggering other major ethnic shifts. The Karluks, in turn, attacked the Oghuz (Uzes) en masse, occupying their nomadic settlements, which provoked an immediate reaction on their part, because the loss of these pastures posed a serious threat to the continued existence of their people. ${ }^{76}$ Faced with a similar threat, they decided to invade the territory of the Pechenegs. The Kimäk tribe and especially their western Kipchak group could also have been involved in these events. However, this last scenario is only possible if the clashes described by al-Masudi pitting the Magyars and Pechenegs against the Karluks, Kimäks and Uzes in the Aral Sea region can be dated to the end of the 9th century and linked to the expansion of the Samanids. ${ }^{77}$

At this point we are faced with a key question: was it just the Uzes or a whole coalition of peoples hostile to the Pechenegs who entered into an agreement with the Khazars? It should be noted that the question of a possible alliance remains an open question, despite Constantine viI's rather unambiguous account. There seems to have been a commonwealth of interests between the two potential partners that favoured the formation of such an alliance. The Khazars may have sought to rid themselves of an inconvenient neighbour, while the Oghuz, who had strong motivations to fight, were well suited to achieving this goal. A joint attack, in which other vassal ethne under the Khazars may have also participated, offered the opportunity to completely annihilate the Pechenegs, or weaken them to such an extent that they would be reduced to a weak ethnic union that could be easily controlled.

The Khazars, however, were risking a great deal. First, there was nothing to guarantee they would have better relations with their new neighbours than with the Pechenegs, who were at a comparable level of development. Al-Mas'ūdì's The Meadows of Gold, contains information that seems to indicate very clearly that the subsequent relations between the Khazars and the Oghuz were terrible. In a report on an expedition by the Rus' that took place after 912/13, al-Mas'ūdì writes that the Oghuz had a practice of taking advantage of the Volga freezing over in winter to organize invasions of the Khazar lands. ${ }^{78}$

76 Györffy 1972, 168-174 (Györffy proposes a slightly different interpretation. The Oghuz' aggression would have been caused not by the loss of their encampments by the Aral Sea, but simply by their desire to enlarge their territory at the Pechenegs' expense. The breakdown of the state of the Karluks, the Oghuz' eastern neighbours, was supposed make this goal easier to achieve); Kristó 1996, 182. Cf. also footnote 37 .

77 Cf. footnote 18. Numerous scholars accept the above interpretation: Macarteney 1929, 343; 1968, 72; Kumekov 1972, 58-9; Zimonyi 1990, 168-9.

78 al-Mas'ūdī, Les Prairies 1863, 19; Pellat 1962, 165. 
Secondly, in the event of failure, even partial failure, the Pechenegs would be able to maintain their political integrity and, as happened in reality, move into the Black Sea steppe, thereby undermining the political and economic interests of the Khazars in the region..$^{79}$ In view of such high risks, it would have been much more rational to take steps to maintain the status quo in the Volga region. The aggression of the Pechenegs who occupied this area did not pose such a serious threat to the Khazars' interests, all the more so given that the penal expeditions undertaken by successive Khazar beys probably limited its scale. A similar interpretation, one which rules out the existence of any cooperation between the two peoples, seems to be justified by the passage from Chapter 38 of De administrando imperio cited above. There is no mention in it of any supposed military cooperation between the Oghuz and the Khazars. The war mentioned by the author was probably an attempt by the Pechenegs to occupy part of the Khazars' territory, following an attack by their eastern neighbours. This attempt was clearly unsuccessful, but because it was impossible for the Pechenegs to retreat to their old encampments, they had no alternative other than to cross over to the right bank of the Volga. ${ }^{80}$

How can the information written by Constantine VII Porphyrogenitus in Chapter 37 be explained? We need to remember that these were very violent ethnic shifts, and this is probably reflected in their speed. We can assume that clashes between the Oghuz and the Pechenegs, and then between them and the Khazars, were separated by a very small space of time. As a result, the oral tradition from which Constantine viI Porphyrogenitus drew his information about these events could easily have been distorted, and instead of information about two failures, the memory could have been preserved of just one failure resulting from cooperation between the Oghuz and the Khazars. If it is also correct to assume that Chapter 37 of De administrando imperio was based on accounts from Pecheneg informants, then we can find another motive that would lead to combine two shameful defeats into one and likewise explain

79 The loss of the Black Sea steppe would have increased the importance of the Itil-Bulgar-Kiev-Kraków trade route, which in combination with the conquests of the Rus' princes, would have had a highly negative impact on the Khazars' interests in the region. Lewicki 1956, 34; Novosel'tsev 199o, 211; Romashov 2004, 222; Kovalev 2005, 80, 104-105, Zimonyi 2016, 278, 324, 352. For a more cautious interpretation: Zhivkov 2015, 123-146, 16 o. Cf. also Chapter 4.2 of the present book.

8o For a similar interpretation: Zimonyi 1990, 174-5; Kristó 1996, 182 (he assumes here, however, that the conflict between the Pechenegs and both the Oghuz and the Khazars took place at roughly the same time). 
the alleged collusion between their eastern and western neighbours. This is a deeply wounded sense of pride. ${ }^{81}$

Unfortunately, we do not know what direction the Pechenegs' road to the Black Sea took. A lack of source data allows us only to assume that it would have been easier for them to move through areas belonging to the weaker of their two western neighbours, i.e., the Burtas. Having found themselves on the right bank of the Volga, the Pechenegs - as previously mentioned - came into contact with the Magyars. The history of the conflict between these two peoples is presented to us by Constantine VII in three chapters of his work. We read in Chapter 37:

The Pechenegs fled and wandered round, casting about for a place for their settlement; and when they reached the land which they now possess and found the Turks living in it, they defeated them in battle and expelled and cast them out, and settled in it, and have been masters of this country, as has been said, for fifty-five years to this day. ${ }^{82}$

In the next chapter, he adds:

The nation of the Turks had of old their dwelling next to Chazaria, in the place called Lebedia after the name of their first voivode, which voivode was called by the personal name of Lebedias [...]. Now in this place, the aforesaid Lebedia, there runs a river Chidmas, also called Chingilous. ${ }^{83}$

Next, after the information about the Pechenegs' defeat in their war with the Khazars and their exodus to the lands of the Magyars, the author writes:

81 Bury 1906, 567-568; DAI-Com., 143; Macartney 1968, 82-86.

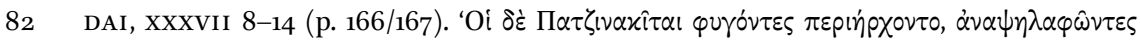

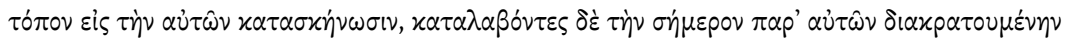

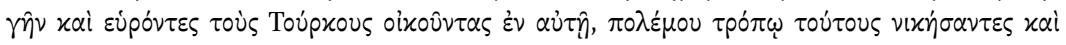

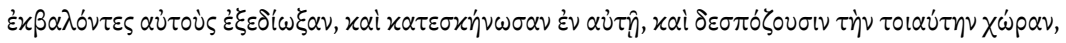

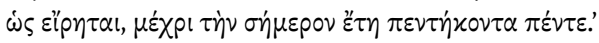

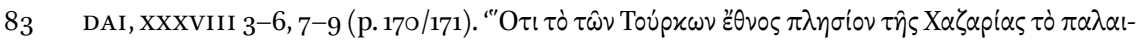

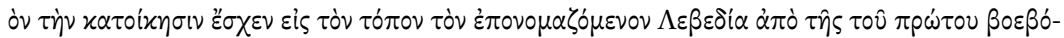

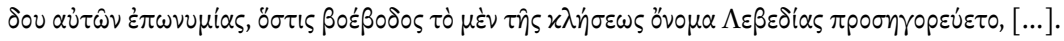

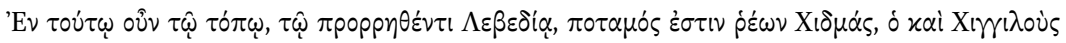

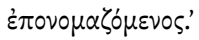


And when battle was joined between the Turks and the Pechenegs who were at that time called 'Kangar', the army of the Turks was defeated and split into two parts. One part went eastwards and settled in the region of Persia, and they to this day are called by the ancient denomination of the Turks 'Sabartoi asphaloi'; but the other part, together with their voivode and chief Lebedias, settled in the western region, in places called Atelkouzou, in which places the nation of the Pechenegs now lives. ${ }^{84}$

In the same chapter, Constantine VII Porphyrogenitus presents the circumstances of the abdication of Lebedias and the assumption of power over all the Magyar tribes by Arpad and his race. It is significant that the new leader

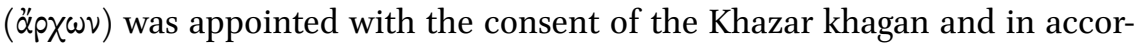
dance with a ritual typical of them. ${ }^{85}$ After this information, the narrative of the De administrando imperio returns to issues of particular interest to us:

Some years later, the Pechenegs fell upon the Turks and drove them out with their prince Arpad. The Turks, in flight and seeking a land to dwell in, came and in their turn expelled the inhabitants of great Moravia and settled in their land, in which the Turks now live to this day. ${ }^{86}$

Finally, in Chapter 40 of Constantine vir Porphyrogenitus' work we read:

$[\ldots]$ at the invitation of Leo [...] they crossed over [Magyars - A.P.] and fought Symeon and totally defeated him, and drove on and penetrated as far as Preslav, having shut him up in the city called Moundraga; and they went back to their own country. [...] But after Symeon was once

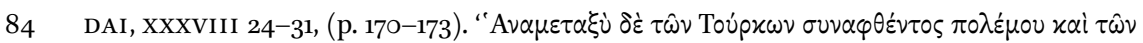

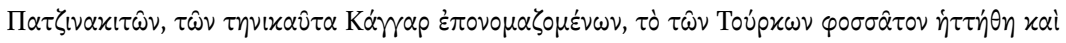

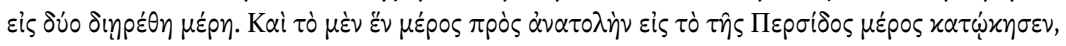

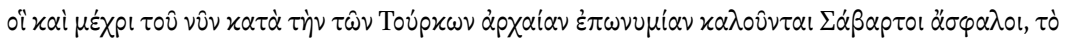

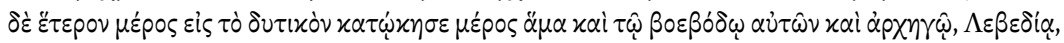

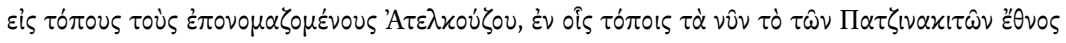

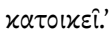

85 DAI, XXXVIII 31-55 (p. 172). Cf. DAI-Com., 148-149; Várady 1982, 49-53; Kristó 1996, 159168 (Kristó corrects the account of Constantine vir Porphyrogenitus and suggests that it was Arpad's father, Álmos, who became Hungary's first military leader and prince).

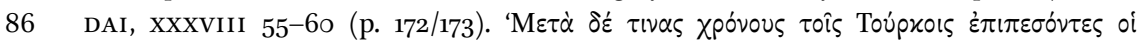

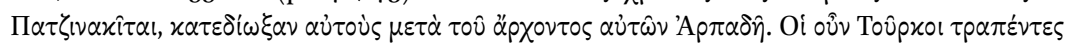

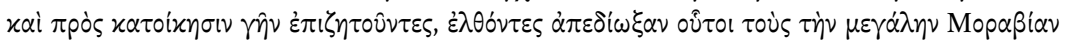

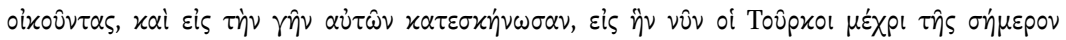

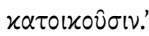


more at peace with the emperor of the Romans and was free to act, he sent to the Pechenegs and made an agreement with them to attack and destroy the Turks. And when the Turks had gone off on a military expedition, the Pechenegs with Symeon came against the Turks and completely destroyed their families and miserably expelled thence the Turks who were guarding their country. When the Turks came back and found their country thus desolate and utterly ruined, they settled in the land where they live to-day $[\ldots] .^{87}$

The accounts cited above have been and continue to be the subject of endless commentary, the main purpose of which has been to clarify three contentious issues. The first is the chronology of events. While it was relatively easy to set a date for the final expulsion of the Magyars from the Black Sea steppe, the moment of their first clash with the Pechenegs has not been precisely determined. The second issue is closely related to the first, i.e., whether in fact the Magyars were defeated twice by the Pechenegs and forced to leave their homeland. The third issue is the question of the location and mutual relationship of the two geographical lands inhabited by the Magyars before they migrated to their Carpathian territories. The value of the above-mentioned passages as source material has been assessed in different ways. The relatively clear and easy to interpret passages from Chapters 37 and 40 have been contrasted with the very confusing narrative of Chapter 38. Hungarian academics, who for understandable reasons have shown particular interest in the aforementioned parts of Constantine viI Porphyrogenitus' work, have applied nearly every available method of interpretation to them. ${ }^{88}$ The information in Chapter 38 has often been described as having no value for reconstructing the actual course of events. A functional analysis has sometimes taken the place of a strictly historical interpretation. There are story lines in the accounts of Constantine VII's Magyar informants that are clearly intended to explain or even legitimise the political changes that took place within the Magyar tribal

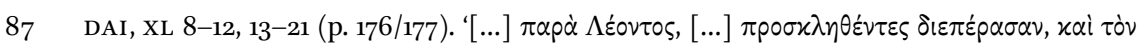

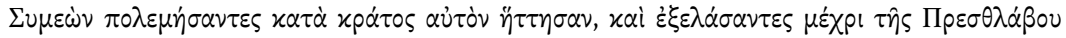

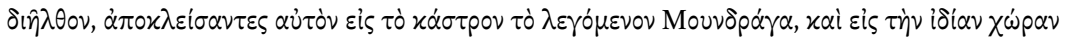

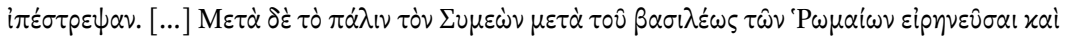

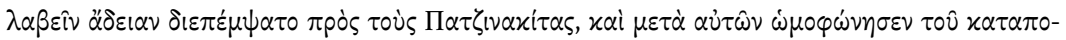

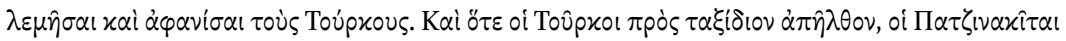

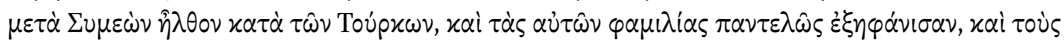

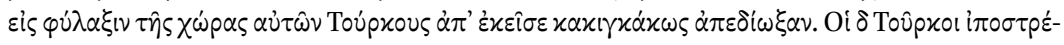

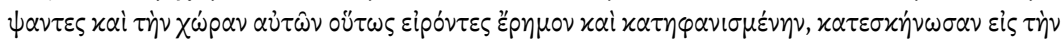

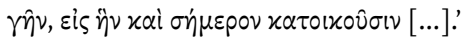


federation in the 9th century. An example of this is the story of Lebedias' 'abdication' and ceding of power to the Arpads. It is hard to deny the accuracy of these kinds of charges. On the other hand, a complete rejection of the information contained in Chapter 38 of De administrando imperio would hardly be justified. Convincing answers to some of the questions raised in his very complicated narrative have yet to be found. However, such a state of affairs does not justify a sometimes overly arbitrary questioning of the reliability of the information it contains.

Efforts have been made to establish the chronology of the fighting between the Pechenegs and the Magyars using information from the Chronicon of the abbot Regino of Prüm. He noted that in 889 the Hungarians (gens Hungarium) were expelled from their lands by the Pechenegs (Pecinaci), who surpassed them in numbers and bravery. ${ }^{89}$ According to Regino, at the time of the Pechenegs' attack the Magyars also occupied the areas surrounding the mouth of the Don, which has inclined some researchers to consider the date given by him as the moment of the first clash between the two ethne, and as a result of which the Magyars left Lebedia. ${ }^{90}$ Such a chronology was adopted by, among others, C.A. Macartney. In his opinion, the Pechenegs first appeared in areas west of the Volga as early as ca. 88o. Their migration was said to be the result of ethnic shifts in Eurasia. An additional argument was that of a brief mention of the defeat of a large number of Pechenegs by Askold and Dir. ${ }^{91}$ However, this information comes from a late compilation (16th century) of the Nikonian Chronicle and was moreover placed under a date inconsistent with that proposed by Macartney $(867) \cdot{ }^{92}$

J. Marquart presented a diametrically different concept, completely ignoring the account of Regino of Prüm. He claims the first Magyar-Pecheneg clash took place around 862. The basis for such an assumption is information provided by Hincmar of Reims about the ravaging of Louis the German's East Francia by the Magyars. ${ }^{93}$ According to Marquart, their military activity in Western Europe testifies to their abandonment of the Sea of Azov and their relocation

89 'Gens Hungarium [...] a Scythicis regnis et a paludibus, quas Thanais sua refusione in inmensum porrigit, egrssa est. [...] Ex supradictis locis gens memorata a finitibus sibi populis, qui Pecinaci vocantur, a propriis sedibus expulsa est, eo quod numero et virtute prestarent [...]'. Regino, 131, 132.

$90 \quad$ DAI-Com., 144, 148.

91 Macartney 1929, 343; 1968, 69-79.

92 PNL, AM 6375 (AD 867), p. 9. Cf. Sielicki 1968, 225 (n. 1).

93 Ann.Bert., sub anno 862, p. 458. Constantine-Cyril, Methodius' brother, encountered Magyars in Crimea at roughly the same time. VCM, 33 (original), 57 (trans.). 
to areas west of the Dnieper River. ${ }^{94}$ The observations of the German scholar are important for dating the presence of the Magyars on the Black Sea steppe. Since they were able in the early 86os to organize an expedition to the other side of the Carpathian Mountains, it is reasonable to assume that they had to control at least the western parts of the Black Sea steppe at that time. However, this is not a clear indication of their loss of control over the eastern part of that region. It is also worth noting that according to a Byzantine chronicler, as early as in 836, a group of Turks helped the Bulgar Khan Presian suppress an uprising by former citizens of Adrianople (Hadrianopolis), who had been resettled during the time of Krum on the Lower Danube. ${ }^{95}$ If the allies of the Bulgarian ruler are identified with the Magyars, their presence on the Black Sea steppe in the 83os should seriously considered. However, their involvement in fighting on the Lower Danube proves nothing more than the fact that they were already regarded by their neighbours as a worthwhile ally.

György Györffy is highly sceptical about the possibility of establishing the date for the first attack of the Pechenegs on the basis of the chronology in Regino of Prüm's Chronicon. Györffy proves that the aforementioned mention was not made in 889, but somewhat later, probably in 906-908. His main argument is the repetition of specific names with names appearing with information incorrectly dated to $901 .{ }^{96}$ In addition, other observations by Györffy seem to exclude the possibility of using this source to determine the date of the Pechenegs' first attack. He correctly points out that Regino writes about only one and not two clashes between these two peoples as the reason for the Magyars leaving Scythia. No other interpretation is possible, since it is hard to imagine that a monk writing in Lorraine would have noted information concerning ethnic shifts within the Black Sea steppe. Such events were part of the internal affairs of the steppe, and not of much interest to Western European citizens. ${ }^{97}$ The situation would have been completely different if the Magyars had left Scythia and arrived in Pannonia, since by that time, migration had become a phenomenon of enormous significance. It was followed by invasions that until the mid-1oth century impacted almost the whole of Western Europe. The earliest of them was recorded by Regino himself, who died in 915 . Therefore, the mentions in the Chronicon cannot provide a basis for setting the date of the first attack of the Pechenegs. ${ }^{98}$ Its chronology is all the more

94 Marquart 1903, 33 .

95 Georg.Mon., 817-818. Cf. Varady 1982, 24.

96 Györffy 1975, 285-286.

97 Györffy 1975, 284-285.

98 Despite the reservations listed above, this was recently accepted by S.A. Romashov (1999, 24; 2004, 221). 
doubtful given that the ethnic shifts that led the Pechenegs to leave the Volga region had already begun, as we established above, around 893. The Pechenegs could have arrived on the Black Sea steppe only after that date. The final exodus of the Magyars from this area occurred no later than in $896 .{ }^{99}$ Such a date seems to confirm the accounts of Byzantine sources, which mainly recorded events related to the Byzantine-Bulgarian war of 894-896, and of Latin sources, which recorded the process of the Magyars' assuming control of the Carpathian Basin. ${ }^{100}$ One extremely important conclusion can be drawn here - namely, that if there were two wars between the Pechenegs and the Magyars, and both took place on the Black Sea steppe, then they would have to have been divided by a small space of time. If that were indeed the case, it is unlikely that they would have been seen in the sources as two separate clashes.

The case is similar with the second disputed issue, i.e., did the two wars actually take place between Pechenegs and the Magyars - and if so, where did they take place? The only account from which we learn details about the two attacks by the Pechenegs is Chapter 38 of De administrando imperio. The author makes it clear that the first attack occurred when the Magyars lived in Lebedia, and its immediate consequence was the splintering of the ethnos into two groups, one of which migrated west to Atelkouzou, while the other went east to Persia. Most researchers assume that the target of the latter group's migration was not Persia itself, but Armenia, which had repeatedly found itself under Persian rule. ${ }^{101}$ Another target destination was proposed by László Várady, who assumed that the Sabartoi asphaloi emigrated to Persian Khorasan. ${ }^{102}$

However, much more interesting than this Magyar sub-group's new home is the name they used for themselves. In its original form it was written: $\Sigma \alpha \dot{\beta} \alpha \rho \tau$ tor $\ddot{\alpha} \sigma \varphi \alpha \lambda o$. According to Marquart, it is associated with the Armenian name Sevordik or 'Black Sons'. Marquart claims it is derived from the ethnonym of the Sevortioi people, who are found in Constantine viI Porphyrogenitus' De cerimoniis aulae Byzantinae. They were said to live somewhere in Transcaucasia (Georgia or Armenia) and their leaders received imperial orders (keleuseis) from the Byzantine rulers. This last fact indicates the Sevortioi's dependence on

99 These circumstances seem to have been ignored by Constantin Zuckerman (1998, 666 (n. 11)).

100 Georg.Mon., 853-855; LeoGramm., 257-268; Th.Cont., 357-36o; Sym.Magist., 275-278; Io.Scyl., 176-177; Ann.Fuld., 129-130. For more on the Byzantine - Bulgarian wars in the years 894-896: Leszka 2013, 76-95.

101 Marquart 1903, 36-37; Macartney 1968, 88-89; Łowmiański 1975, 61. Cf. Kristó 1996, 138-141.

102 Varady 1982, 27. 
Constantinople. ${ }^{103}$ Marquart suggested that this was a distortion of an ethnic name that was actually Sev-Ogrik, or 'Black Magyars', ${ }^{104}$ which would be evidence that Constantine VII was not mistaken about their possible association with the sub-group of that people that later crossed the Carpathian Mountains.

However, a closer analysis of the accounts found in sources concerning the people referred to as the Sabartoi asphaloi raises further interpretative challenges. They were known to Arab writers as as-Savardiya, and are mentioned under this name for the first time by al-Baladuri. From his accounts we learn that they attacked the city of Shamkur in Armenia. According to Marquart, this attack took place between 750 and $760 .{ }^{105}$ Macartney, in turn, believes that this did not mark the period when the Magyars resettled in the South Caucasus, but represented a solitary expedition carried out, most likely, with the consent of the Khazar rulers, whom they served. ${ }^{106}$ The Sevordik, however, are not mentioned by Armenian sources as permanent residents of Armenia until the mid-9th century. ${ }^{107}$ Therefore, it is sometimes assumed that their resettlement could have taken place sometime between 830 and 840 ; it is also likely that there was a disintegration of the Magyar community at that time. ${ }^{108}$ The same conclusion is reached by Pritsak. In his research, however, he relied on ibn Rusta's information about the 'first border of the Magyars', mentioned earlier in this chapter, which is said to come from a work by another Arab author, al-Khwārizmī, written no later than in 833. The rest of the information about the Magyars, which concerns their time on the Black Sea steppe, was taken by ibn Rusta from al-Jarmī, who, in turn, could not have written his work earlier than around $840 .{ }^{109}$

The chronological data obtained during earlier studies seem to suggest that the first Kangar/Pecheneg war with Magyars/Sabartoi asphaloi took place at least a half a century before the clash that resulted in the latter people's exodus from the Black Sea steppe. This observation also seems to lead to the logical conclusion that the Volga region must have been the site of the earlier conflicts. According to the accounts of Constantine VII, this is also the area where we should locate Lebedia. Such an interpretation is difficult to accept

\footnotetext{
103 DCB 1, II 48, 13-14, (p. 687); Moffat, Tall 2012, 687. Cf. Róna-Tas (1999, 418-420) questions the existence of the Sabartoi asphaloi, considering them a product of Constantine VII Porphyrogenitus' erudion. It is hard to accept his opinion.

104 Marquart 1903, 36.

105 Marquart 1903, 37; Macartney 1968, 88. Cf. Dunlop 1954, 202.

106 Macartney 1968, 90.

107 Macartney 1968, 9o. In the year 853, to be exact.

108 Łowmiański 1973, 61-62; Kristó 1996, 147-148.

109 Pritsak 1976, 19.
} 
by researchers, however, who are inclined to place Lebedia on the Black Sea steppe. Macartney attempted to resolve this contradiction by demonstrating that the disintegration of the Magyars occurred as a result of an attack not by the Pechenegs, but by a Caucasian tribe, the Cherkess (Circassians), mentioned by al-Mas'üdī as the Nandarin. Constantine VII Porphyrogenitus identified them as the same group, partly in error, and partly in order to point out the important role played by the Pechenegs in shaping the political relations in the Black Sea region. The Cherkess invaded the Magyars at a time when the latter lived in areas north of the Kuban River. ${ }^{110}$ This or a similar location would seem to be beyond dispute, first because this would mean the Magyars neighboured the Cherkess, which is a necessary condition for the possibility of a conflict between the two ethne; secondly, such a location is tentatively supported by the consequences of an event mentioned here earlier numerous times: if the Magyars' defeat led directly to the disintegration of their original ethnic community and to the migration of the Sabartoi asphaloi to the South Caucasus, the conflict would very likely have taken place in the environs of the Kuban. According to further findings by Macartney, the western faction of the Magyars went to Lebedia, where it was again attacked, this time by the Pechenegs. ${ }^{111}$ Since Macartney is willing to accept, as does John Bagnell Bury, that De administrando imperio is only a loose, collection of notes from various sources and drawn up at different times, ${ }^{112}$ lacking deeper analysis, he therefore considers that Chapter 38 provides information only on the first clash between the Pechenegs and the Magyars. The circumstances of the second conflict between the two peoples would therefore be presented only in Chapter 40. ${ }^{113}$

A different way of resolving this troublesome contradiction is a concept proposed by Henryk Łowmiański, who, unlike Macartney, considered the passage in Constantine VII's work concerning the disintegration of the Magyar community to be credible. However, the author of The Origins of Poland (Poczatki Polski) located the Pechenegs' first attack in the Volga region, when the Magyars lived within the territory of what would later become Bashkiria. Archaeological data from the vicinity of the Belaia and Kama Rivers, as well as a passages from ibn Rusta, seem to confirm the possibility of a conflict between the two ethne during their nomadic period east of the Volga. After the defeat of the Sabartoi asphaloi, they are said to have travelled to the South Caucasus along the Volga, while a second group of Magyars reached Levedia following a

\footnotetext{
110 Macartney 1968, 103, 106-108.

111 Macartney 1968, 108.

112 Bury 1906.

113 Macartney 1968, 8o-83, 96-103.
} 
path the led down the Don. Łowmiański's final conclusion was based on topomastic data collected in the Kazan, Tambov and Simbirsk Governorates. ${ }^{114}$

It seems that the two hypotheses presented above, both aimed at clarifying the troublesome discrepancies contained in Chapter 38 of De administrando imperio, unfortunately raise a number of additional doubts. In terms of Macartney's reasoning, the method of criticism he applied to Constantine vII Porphyrogenitus' account needs to be approached with considerable scepticism. Based on J.B. Bury's well researched findings, Macartney goes one step further - namely, he tries to prove that the accounts that gave Chapter 38 of De administrando imperio its final shape concerned a single clash between the Pechenegs and the Magyars, but the fact that they came from various informants could have led to an accidental 'doubling' of the battles between the two peoples. However, in the absence of any alternative source describing in equal detail the events connected with the Pechenegs' journey to the Black Sea steppe, such a conclusion exposes its author to accusations of having made arbitrary choices in the treatment of data. ${ }^{115}$ The identification of the Cherkess/Nandarins with the Kangar is also highly questionable. Constantine VII states twice that the Pechenegs used to be called Kangar. This claim arouses Macartney's scepticism, who quite rightly notes that the Pechenegs had never appeared earlier under such a name (at least in the sources known to us), which indicates that they were not the same as the Kangar. ${ }^{116}$ This last argument would fully justify Macartney's assumptions if not for a reference made at the end of Chapter 37 of De administrando

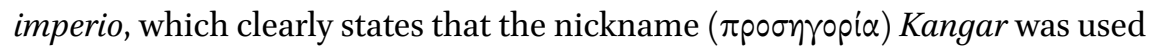
in reference only to the bravest members of the Pecheneg tribe ( $\alpha \nu \delta \rho \varepsilon$ ó $\tau \varepsilon \rho \circ)$

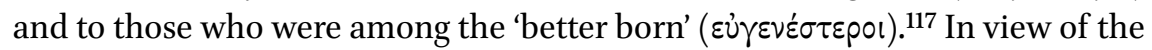
such a finding, Macartney's argument is proved inconclusive, a fact of which he is aware and he thus questions the value of the above mention, demonstrating that the word 'kangar' does not have the meaning attributed to it by Constantine VII Porphyrogenitus in the Old Turkic language. However, if we acknowledge that the Byzantine emperor did not make such a statement expresis verbis, but offered it only as one possible interpretation, then Macartney's linguistic analysis, regardless of its results, seems totally misguided and incapable of achieving the desired outcome. ${ }^{118}$ It is also difficult to accept the

\footnotetext{
114 Łowmiański 1973, 62-67.

115 Łowmiański $1973,58$.

116 Macartney 1968, 106.

117 DAI, XXXVII 68-71 (p. 170).

118 Macartney 1968, 104-106.
} 
argument that Constantine VII would have attributed to the Pechenegs a victory over the Magyars in which they actually played no role when his intention was to demonstrate to his son the political significance of this people. The learned basileus had enough real examples to illustrate this thesis that he did not have to resort to a more or less deliberate fabrication. ${ }^{119}$ Finally, the placement of the Magyars on the Kuban River is also questionable. This hypothesis rests on a weak source base. It would seem more justified to place the Black Bulgars in this region. ${ }^{120}$ Their existence is confirmed by Constantine VII Porphyrogenitus in the middle of the 1oth century. The emperor writes about them twice. In Chapter 12 of the De administrando imperio he assumes they are capable of attacking Khazaria, while in Chapter 42 he suggests that their territory is located near the Azov Sea. ${ }^{21}$ Both pieces of information seem to confirm the location we have adopted as likewise being valid in the mid-1oth century. Macartney's hypothesis that the territory north of the Kuban River could have been inhabited by Magyars in the first half of the 9th century is thus rather unlikely. ${ }^{122}$

The second hypothesis cannot be accepted without reservation. If the Magyars, as Łowmiański claims, left Bashkiria as a result of Pecheneg invasions, then we need to ascertain their character. In other words: was their aim to conquer the territory of their neighbours, or did they only carry out systematic looting attacks, without any attempt to seize the Magyars' nomadic settlements? The first possibility clearly seems to be indicated by the account provided by Constantine vil Porphyrogenitus. From the troublesome mentions found in Chapter 38 of De administrando imperio, it can be deduced that the Kangar, having expelled the Sabartoi asphaloi, then occupied their lands. However, it is unclear why they should have done so in the period between 830 and 840 . The easiest thing to assume would be that at this time some kind of migration was taking place which encompassed large areas of the steppe. This is what Golden suggests. His interpretation was rejected, however, because the chronology of the source data on which he based his reasoning was questionable. Another reason this problem is worth considering because Łowmiański seems to suggest that the Pechenegs occupied at least part of Bashkiria, pointing to a tribal name still found in this land - Youmalan, which the researcher associates with the Pecheneg and not the Magyars. ${ }^{123}$ This is the first reservation.

\footnotetext{
119 Macartney $1968,108$.

120 Cf. Chapter 2 of the present book.

121 DAI, XII (p. 64/65); XLII (p. 186/187).

122 For more on the question of what lands were inhabited by the Black Bulgars: Łowmiański 1973, 65, fig. 2; Wozniak 1979, 120-121; Zhivkov 2015, 136-140.

123 Łowmiański 1973, 62.
} 
The second is as follows: if a direct result of the first invasion of the Pechenegs was the disintegration of the Magyar community, which seems to be the case in the account of Constantine vir Porphyrogenitus, then any attempt to date these events to a later time is unjustified. Nevertheless, this is what Łowmiański did, claiming that before the Sabartoi asphaloi separated from the rest of their brethren, they travelled with them over a long stretch of road until they reached the mouth of the Kama, and only then headed south, while the rest of the tribe went westwards. What is more, Łowmiański allows that both groups may have reached Lebedia, where the break-up occurred.124 This land is also located on the Black Sea steppe.

A satisfactory solution to all the problems associated with the first clash between Pechenegs and Magyars - or rather, if we adopt the timeline of Constantine VII Porphyrogenitus' narrative, between the Kangar and the Sabartoi asphaloi - would seem to be impossible, especially one based on the information contained in extant sources. The picture of political relations in the Volga region in the 830 a and 84 os looms as very complicated. At this time, the Khazar Khaganate seems to have been experiencing a crisis, which was accompanied by major power shifts within it. If so, the state would have been vulnerable to exploitation by hostile political entities such as the Pechenegs. The Lebedias' tribes, allies of the Khazars, were most likely also victims of Pecheneg aggression.

An extremely interesting issue is the relation between these events and the rebellion of the Kabars. From Chapter 39 of De administrando imperio we learn that they were originally among the tribes of the Khazars, but found themselves in conflict with its rulers, rebelled, were defeated and seceded from the tribe. They eventually merged with the Magyars and settled with them in Atelkouzou. ${ }^{125}$ The centrifugal nature of the Kabars' political aspirations could have, but not necessarily made them natural allies of the Pechenegs. ${ }^{126}$ In any case, it contributed to temporary instability in the Pax Chazarica, which the warrior neighbours of the Khaganate tried to use to their advantage. However, this crisis was eventually overcome; the Khazars managed not only to hold back the Pechenegs, but also to maintain at least nominal control over the Black Sea steppe. The merger of the defeated Sabartoi asphaloi faction with the Kabars gave rise to a new political organism, which most likely harboured

\footnotetext{
124 Łowmiański 1973, 67.

125 DAI, XXXIX, (p. 174/175).

126 Cf. Bartha 1975, 63-64. Bartha assumes that the Pechenegs took the side of the Khazars in the Kabars' revolt. But this interpretation seems to contradict both data gathered by Constantine VII and information found in Arabic sources.
} 
no hostilities towards the Khazars. On the basis of the complicated narrative in Chapter 38 of De administrando imperio, I believe that after the secession of the Kabars and their domination of the Magyar tribal union, a compromise was reached between the former rebels and the Khaganate. ${ }^{127}$ In exchange for formal recognition of the sovereignty of their rulers, they were granted considerable independence. They made eager used of this, especially in the latter half of the gth century, when they began to penetrate areas west of the Carpathians militarily. In spite of internal crisis and external pressures from its enemies, the Khaganate managed to maintain its influence on the Black Sea steppe. Their hegemony would come to an end only in the last decade of the 9th century as a result of Pecheneg migration.

Despite all the doubts expressed above, we can assume there were two wars between the Pechenegs and the Magyars. It should be noted, however, that the first clash was part of a series of events that contributed to the ethnogenesis of the Magyars, whom Byzantine authors called 'Turks'. If we follow the ethnic terminology used by Constantine viI Porphyrogenitus, then we should say that Lebedias' tribes known as the Sabartoi asphaloi had to face the Kangar, or - if the last ethnonym is treated as a pars pro toto of the whole ethnos - with the Pechenegs. As a result of their defeat, a sub-set of the defeated group, perhaps with the consent or even inspiration of the Khazars, migrated to the Black Sea steppe. ${ }^{128}$ In the course of their migration, or after they had arrived in their new home, they merged with Kabars. ${ }^{129}$ This was one of a series of events that led to the creation of a new political organism, i.e., the ethnogenesis of Magyars. The merger of these two groups was probably peaceful, as evidenced by the fact that in the 88 os both remained ethnically distinct. ${ }^{130}$ Nevertheless, the new political system, as Constantine viI clearly indicates, had a much more centralized structure than the loose confederation led by the Lebedias. ${ }^{131}$ The compromise reached with the Khazars, a sign of which was the elevation of Arpad to power, ${ }^{132}$ defined the place of the Magyars within the Pax Chazarica, i.e., within the political relations of Eastern Europe at the time.

\footnotetext{
127 DAI, XXXVIII 31-55 (p. 172/173).

128 Cf. Várady 1982, 27.

129 Cf. Bartha 1975, 63; Várady 1982, 30; Kristó 1996, 150-151 (contains a breakdown of different viewpoints on Hungarian histography).

130 Ann.Iuv., sub anno 881 (p. 742). According to these accounts, the entire tribal union forayed west, reaching Vienna. The Kabars remained allied with the other tribes, but operated independently. Cf. Kristó 1996, 15 o.

131 DAI, XXXVIII 53-55 (p. 172/173). Constantine VII stresses that the Turks (Magyars) did not have a monarch before Arpad.

132 DAI, XXXVIII 51-53 (p. 172/173).
} 
We can therefore see that the first defeat in the struggle against the Pechenegs was a fundamental event for the Magyars, since it initiated a series of events that ultimately led to the formation of their community, both in terms of its ethnic composition and its political structure. These circumstances most likely determined how these events were preserved within the Magyar oral tradition, which was the basis for the accounts of Constantine vir. We should acknowledge the claims of those researchers who place this clash in the Volga region, although such an interpretation will pose further problems for us.

At this point, we should proceed to analyze the third and last of the issues mentioned above, i.e., the location of the two geographical lands mentioned by Constantine VII Porphyrogenitus: Lebedia $(\Lambda \varepsilon \beta \varepsilon \delta i \alpha)$ and Atelkouzou

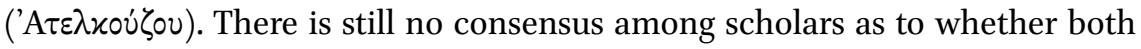
lands were located in the Black Sea steppe region. ${ }^{133}$

Lebedia's location raises more difficulties, as linguistic analysis has not produced clear results. Since, according to Constantine VII Porphyrogenitus, the name of the land was to come from the name of the Magyar voivode Lebedias, some researchers assume that its source is the Old Hungarian term for steppe areas - lebedi. ${ }^{134}$ Another proposal for deciphering its etymology was presented by Macartney, for which it is a Slavicized term meaning 'a place containing many trees and water, where the soil is wet and swampy'.135 Still other researchers believe that the word's etymology is derived from the Hungarian root lel-, which appears in such words such as lelek - spirit, soul.'.136 We can thus see that not only is there no fundamental agreement on the origin of the word $\Lambda \varepsilon \beta \varepsilon \delta i \alpha$, but also that the results of linguistic analyses are of doubtful value in determining the location of this land.

Much more worthy of mention are the attempts to identify the river Chidmas/Chingilous, which according to the accounts of Constantine VII Porphyrogenitus, flowed through Lebedia. Some researchers are inclined to see its equivalent in the Molochnaia, a small river flowing into the Azov Sea, formed by Tokmak (a metathesis of its first syllable allegedly appears in the name Chidmas) and the Chingul (Chingilous). Such a resolution can be explained by the fact that the learned basileus recorded two names for the same river. ${ }^{137}$ Łowmiański believed that this was supported by an additional

\footnotetext{
133 Kristó 1996, 107-110.

134 DAI-Com., 147; Swoboda 1967, 30.

135 Macartney 1968, 92-93.

136 Artamonov 1962, 341; Tryjarski 1975a, 512.

137 Marquart 1903, 32; Macartney 1968, 91; Łowmiański 1973, 59; Huxley 1984, 81. Marquart adds that the environs of the Molochnaia River were supposedly still known as Lepedika in the late 19th and early 2oth century. The source of his information, however, is unknown.
} 
argument - namely the location of the Molochnaia River almost exactly along the border of Saltovo-Maiaki culture, which would explain the fact that a relatively small river attained a representative status. ${ }^{138}$

However, even if we assume that Molochnaia was the river Constantine VII had in mind, the matter of defining the borders of Lebedia remains an open question. We do not need, as Łowmiański would like, to recognize the Molochnaia as its eastern border. The account of Constantine viI creates equally valid premises for stating that the Chidmas/Chingilous flowed through the interior of Lebedia, and thus was not a border river. It should also be remembered that there is a historiographical tradition which accepted the fact that the Magyars remained for a significant time in the vicinity of the Don, i.e., in areas located much farther east than the Molochnaia. Similar information can be found in the writings of Regino of Prüm, whose chronicle is of little value for the chronology of events, but according to Hungarian scholars the data they contain can be treated with a high degree of confidence. The Lorraine abbot explicitly mentions that at the time of their attack by the Pechenegs, the Magyars lived in the vicinity of the Tanais (Don). ${ }^{139}$ Traces of a similar textual tradition can be found in the Hungarian chronicles. ${ }^{140}$ It seems, therefore, that the eastern border of Lebedia could have been the Don, rather than the Molochnaia.

Another proposal was made by the Hungarian scholar Géza Feher, who argued that the Chidmas/Chingilous should be identified with the Donets River. ${ }^{141}$ Finally, it was also thought that the river was the same as the Inhul tributary of the Boh. ${ }^{142}$ According to Edward Tryjarski, from a purely linguistic point of view, this is the most probable interpretation. ${ }^{143}$

\footnotetext{
138 Łowmiański 1973, 59.

139 Regino, 131.

140 In particular, in: G.Ung., 34, 39. Cf. Spinei 2003, 52-53.

141 Fehér 1959, 308.

142 Vernadsky 1957, 17 (According to Vernadsky, Lebedia stretched from Podolia and the Inhul area in the west, to the upper Donets and Don in the east, and to the Ugra in the north); Ilinskii 1930, 101 (an identification with the Inhulets, a right tributary of the Dnieper River, is also permissible); Zukerman 1998, 668 (both of these rivers are the Inhul); Kristó 1996, $111 ; 1998,15^{2-154}$ (Kristó assumes that the rivers in question are the Kodyma and Inhul, which means that Lebedia would have been located south of the lower Boh); Múcska 2004, 283; Spinei 2003, 41 (Spinei does not attempt to identify the Chidmas [Chingilous] river, but assumes that Lebedia could have been located between the Volga and Don rivers or between the Don and Dnieper). Cf. also DAI-Com., 147; Litavrin, Novosel'tsev 1989, 392 (n. 3).

143 Tryjarski 1975a, 512.
} 
Far fewer researchers locate the Lebedia in the Volga region. Among them was Gábor Vékony. ${ }^{144} \mathrm{He}$ believed we should look for this land between the Urals and the Aral Sea. The Chidmas/Chingilous was, in his opinion, the same as the Emba. ${ }^{145}$ László Várady identified this mysterious river with the Bolshoi Uzen and Maly Uzen, which means that Lebedia would have been on the steppe between the Volga and the Yaik-Ural. ${ }^{146}$ Our earlier observations concerning the site of the battle between the Sabartoi asphaloi and the Kangar seem to justify locating Lebedia somewhere to the east of the Volga. However, the findings of the archaeologists referred to above do not allow us to accept either of the two hypotheses mentioned above. The homeland of the people with the material culture closest to finds from the Hungarians from the Pannonian area have been located on the Belaia and Kama Rivers, and therefore far north of the Emba river basin or the Bolshoi Uzen and Maly Uzen.

It is worth noting one more circumstance that has become a subject of consideration by numerous researchers. According to Constantine VII, the name of the home of the Sabartoi asphaloi was supposed to be derived from the name of the voivode Lebedias. The credibility of this information has often been questioned. Researchers have emphasized that the construction of the toponym 'Lebedia' cannot be of Hungarian origin, because it is in stark contradiction with the native tradition for creating personal names, which in Hungarian is certainly not the final suffix $-i a{ }^{147}$ It also seems unlikely that a person's name would become a toponym for a great land or province inhabited by a whole people. The Hungarian language allows for this possibility only in the case of small settlements. ${ }^{148}$ In the light of such arrangements, Lebedia could only be the seat of the voivode himself and not of a whole union of tribes. It should be noted, however, that in the realities of the tribal societies that lived on the steppe, a primary factor guaranteeing their survival was their bonds of personal subjection. Territorial ties played a lesser role. Given this situation, Lebedias, as someone who bound individual tribes, naturally united and embodied the whole community. His seat was obviously also the centre of community relations. The centre was thus located where the voivode lived. ${ }^{149}$ Such an ascertainment would render efforts to locate Lebedia completely pointless. It could be located both in the Volga region and on the Black

\footnotetext{
144 Vékony 1986, 42-43, 50-51.

145 For a critical look at Vékony's views: Kristó 1996, 109-110.

146 Várady 1982, 26. Várady does not present any evidence rooted in linguistic research to support his proposed identification.

147 Kristó 1996, 107; Róna-Tas 1999, 418.

148 Kristó 1996, 108; Róna-Tas 1999, 418-419.

149 Cf. Moór 1936, 217; Kristó 1996, 108.
} 
Sea steppe. After all, according to Constantine viI Porphyrogenitus' account, Lebedias would remain at the head of the tribal union even after the defeat he suffered to the Pechenegs. Yet, convincingly identifying references to the Chidmas/Chingilous River remains a key issue in resolving the question at hand.

The location of Atelkouzou raises markedly fewer doubts. In this case, researchers agree more on the etymology of this toponym. In all probability it consists of two nouns: Turkic 'atel/itil/etel' (water, river) and Turkic 'köz' or Finno-Ugric 'küzü' (area, terrain). Thus, the word could mean an area through which several rivers flow, as well as an area situated on one river or between rivers. ${ }^{150}$

In De administrando imperio, apart from the previously quoted passage from Chapter 38, some very important information about Atelkouzou can also be found in Chapter 40:

The place in which the Turks used formerly to be is called after the name of the river that runs through it, Etel and Kouzu, and in it the Pechenegs live now. ${ }^{151}$

The above passage seems to indicate that this is a riverside territory, but we do not have any other information to identify it. Therefore, the majority of researchers wishing to determine the location of Atelkouzou refer to the data contained at the end of Chapter 38 :

The place of the Pechenegs, in which at that time the Turks lived [i.e., the time of the Pechenegs' attack - A.P.], is called after the name of the local rivers. The rivers are these: the first river is that called Barouch, the second river that called Koubou, the third river that called Troullos, the fourth river that called Broutos, the fifth river that called Seretos. ${ }^{152}$

150 Marquart 1903, 33; Macartney 1968, 96; Łowmiański 1973, 59; Huxley 1984, 82; Kristó 1996, 155-156; Múcska 2004, 283; Spinei 2003, 43; DAI-Com., 148, 151; Litavrin, Novosel'tsev 1989, 393 (n. 13).

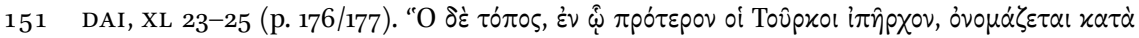

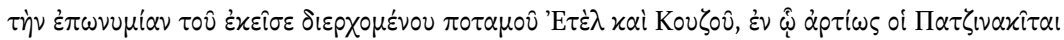

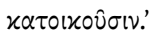

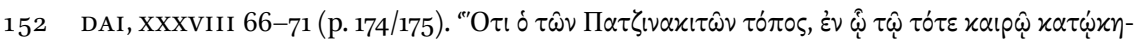

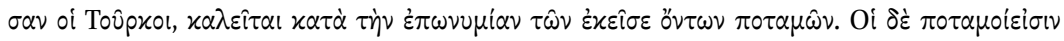

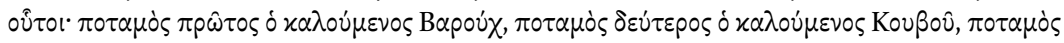

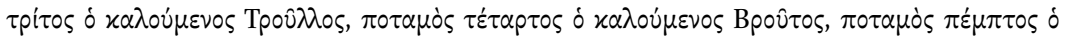

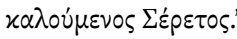


This passage is of paramount importance for further consideration of this topic, mainly because the names of the rivers mentioned in it have been indisputably deciphered. These are respectively: the Dnieper, Boh, Dniester, Prut, and Siret. ${ }^{153}$ Since the above description refers to an area with an abundance of rivers, to which it owes its name, many scholars have been inclined to believe that this is Atelkouzou, although the quoted excerpt does not explicitly mention this name. Supporters of such an interpretation include Marquart and Łowmiański. ${ }^{154}$ In their view, Atelkouzou is a separate land from Lebedia, bounded to the east by the Dnieper River and to the west by the Danube or the Seret. Other researchers (Macartney, Grégoire, Artamonov) are inclined either to stipulate the identity of Lebedia and Atelkouzou ${ }^{155}$ or otherwise define the area occupied by the latter land. ${ }^{156}$ The latter possibility seems to be worthy of consideration, given that the interpretation presented above is not the only plausible one. We could just as well adopt another, according to which, if the aforementioned rivers flowed through the territory of the Pechenegs, its rulers (present and former) would rule on both their right and left banks, so that the Dnieper and Siret would cease to function as the borders of nomadic settlements. Moreover, if we assume that by the term 'the place of the Pechenegs' ( $\delta \tau \hat{\omega} \nu \Pi \alpha \tau \zeta(v \alpha \alpha i \tau \hat{\omega} \nu \tau o ́ \pi \circ \varsigma$ ) Constantine viI Porphyrogenitus understood the whole territory occupied by them in the middle of the roth century, and not only its western part, then it is all the more difficult to accept the hypothesis presented earlier. From his writings it is clear that the lands occupied by the Pechenegs at that time stretched between the Danube and the Don. We must also note that in the passage under discussion, almost all the larger rivers flowing into the Black Sea and the Sea of Azov are mentioned. The only ones omitted are the Don and Danube. The explanation for their absence is relatively simple. The Danube and Don were the borders of the Pechenegs' nomadic settlements, so they did not flow through the territory of these steppe-people. The only circumstance that undermines our interpretation is the lack of an equivalent for the Donets, which does not flow into any sea, but is an important river in the region. It seems, however, that the Chapter 42 of De administrando imperio contains an interesting piece of information that both explains this doubt and supports our reasoning:

\footnotetext{
153 DAI-Com., 149; Litavrin, Novosel'tsev 1989, 394 (n. 26, 27).

154 Marquart 1903, 33; Łowmiański 1973, 59; Huxley 1984, 83; Litavrin, Novosel'tsev 1989, 394 (n. 27).

155 Macartney 1968, 94-96; Grégoire 1937, 635; 1938, 268; Artamonov 1962, 340.Cf. Tryjarski 1975a, 512; Kristó 1996, 154.

156 Györffy 1975, 287.Cf. Spinei 2003, 44.
} 
From the Danube river to the aforesaid city of Sarkel is a journey of 60 days. In this land between [i.e., between the Danube and the Don, on which lay Sarkel - A.P.] are many rivers: the two biggest of them are the Dniester and the Dnieper. But there are other rivers, that which is called the Syngoul and the Hybyl and the Almatai and the Kouphis and the Bogou and many others. ${ }^{157}$

It is clearly stated here that the area between the Danube and the Don is a land of many rivers, and this provides a means for interpreting the name of the territory of the Magyars and Pechenegs - Atelkouzou. It should moreover be noted that according to Constantine viI Porphyrogenitus, the rivers particularly representative for this area are the Dnieper and Dniester, which are also mentioned in the final part of Chapter 38 . The learned emperor mentions several other rivers, including the Syngoul, which can be identified as the Donets, ${ }^{158}$ though he gives them a clearly secondary character. We can therefore assume that:

- The description we find in the final passage of Chapter 38 of De administrando imperio concerns Atelkouzou. This seems to be indicated by the mention that this is the former territory of the Magyars, now inhabited by the Pechenegs. Similar information can also be found in Chapter 40, where the name Atelkouzou is mentioned.

- It is also a description of the entire territory of the Pechenegs, which, according to Constantine VII, stretched in the middle of the 1oth century from the Don to the Danube.

- Atelkouzou covered exactly this same area. The origin of this name becomes understandable for us, especially in the light of the last of the passages of De administrando imperio quoted above. ${ }^{159}$

The issue of Lebedia's mutual relationship with Atelkouzou, in particular in the light of the findings discussed above, cannot be resolved satisfactorily. In order to remain faithful to my own observations as well as to the account offered by Constantine viI Porphyrogenitus, I am inclined to look for the first of the lands in the Volga region. From the information contained in De administrando imperio, it seems that the Sabartoi asphaloi lived in Lebedia and were expelled from it by the Kangar-Pechenegs. If this clash took place somewhere in Bashkiria, it is there that the sought-after land should be located. On the

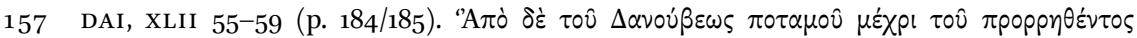

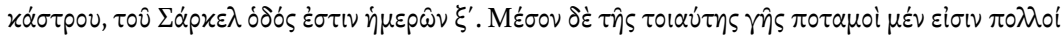

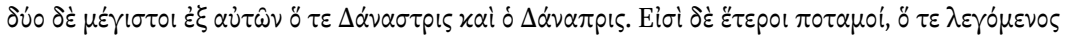

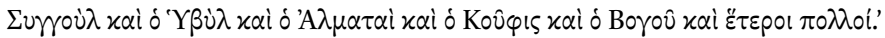

158 Feher 1959, 308.

159 Similar borders for Atelkouzou (Hungarian: Etelköz) were outlined by Györffy 1975, 287.
} 
road to such an interpretation, however, stands the impossibility of convincingly deciphering the name of the Chidmas/Chingilous River.

The possibility of locating Lebedia on the Black Sea steppe therefore remains open. If Lebedia was indeed located there, the question arises as to why it was placed next to Atelkouzou in the Hungarian oral tradition. There seems to be one rather important premise that can explain this fact. The memory of Lebedia may reflect the process of the Magyars' migration onto the Black Sea steppe. It cannot be ruled out that at first they occupied a small area east of the Don, but soon extended their rule to the right bank of the Dnieper River. This seems to be evidenced by the reference in the Annals of Saint Bertin (Annales Bertiniani) to the Magyars' invasion of East Francia, mentioned earlier in reference to Marquart's dating of the first Magyar-Pecheneg clash. ${ }^{160}$ Marquart rightly assumed that if the Magyars were able then to carry out a looting expedition targeted at a Western European power, the borders of their homeland had to extend to the Danube delta. It is difficult to imagine such an attack being possible if the aggressor occupied an area east of the Dnieper. Unfortunately, Marquart mistakenly links this event to the Pechenegs' invasion, but his observation is in general quite valuable. We can therefore conclude that the Magyars conquered the entire area comprising Atelkouzou as early as the 86os. This assumption is confirmed by a number of later sources, indicating indirectly that the Magyars occupied the territories in the environs of the Danube. ${ }^{161}$ Meanwhile, they maintained their sovereignty over the eastern part of the Black Sea steppe. Lebedia, if it was indeed in the area they controlled, was only part of a much larger territory, yet the Hungarians sought to preserve the memory of their original homelands. To some extent, it is therefore appropriate to agree with Łowmiański that Lebedia could have been a kind of starting point for their excursions. The Pechenegs attacked the Magyars for the second time when the latter already controlled the steppe between the Don and the Danube.

Since we have already taken a stance on a number of controversial issues resulting from the aforementioned passages in De administrando imperio, we can therefore attempt now to establish the course of events that led to the establishment of the Pechenegs on the Black Sea steppe. The start of this journey was probably a result of ethnic displacements, in this case caused by the expansion of the Samanid Empire. Around 893 they forced the Oghuz to leave their nomadic settlements and attack their western neighbours, the Pechenegs. The latter, succumbing to the mechanism of the 'migration of peoples', made

16o Marquart 1903, 33. For additional arguments supporting the hypothesis of Magyar expansion onto the Black Sea steppe and beyond: Spinei 2003, 41-42.

161 Cf. Györffy 1975, 287-288. 
an attempt to settle on the territory of the Khazars, which ended in a total failure. Despite this defeat and contrary to Khazar's interests, the Pechenegs managed to cross to the right bank of the Volga at a crossing place that was probably in an area controlled by the Burtas, who were allies of the Khazars but were clearly weaker than them. Information about possible Khazar-Oghuz cooperation against the Pechenegs should be considered unreliable, mainly due to the lack of a motive justifying such a move.

The arrival of the Pechenegs on the Black Sea steppe took place at a rather pivotal moment in history. A war was being fought between Simeon I, the ruler of Bulgaria, and the Byzantine emperor Leo vi (the Wise), father of Constantine VII Porphyrogenitus. Its participants included the inhabitants of Atelkouzou, i.e., the Magyars, who were fighting on the side of Leo VI. When Simeon I found himself in a desperate situation, which we learn about in Chapter 40 of De administrando imperio, he decided to call on the Pechenegs for help. Other Byzantine sources do not note this fact, ${ }^{162}$ which sometimes leads researchers to accept the premise that the nomadic invasion were carried out on their own initiative. ${ }^{163}$ Indeed, the extremely violent nature of events seems to exclude the possibility of the Bulgarians organizing a diplomatic mission aimed at persuading the Pechenegs to fight the Magyars or, more likely, to agree on a joint attack by them and Simeon's troops. The true, or rather unwitting ally, who had just lost his home and was now 'wandering in flight' in search of a new one, had a great motivation to fight that did not have to be reinforced in any way. The Pechenegs were also able to take make good use of the tactical advantage given to them by circumstances. They attacked the Magyars not when they were prepared to repel an attack, but during the absence of their main forces due to a military expedition. The impact of the Pechenegs must have been extremely severe, especially given that Emperor Leo VI abandoned his former allies after entering into a peace agreement with Simeon. As a result, the Magyars were forced to leave their homelands once again, this time the vast lands of Atelkouzou, which the aggressors seized.

Judging by the information contained in Constantine viI's account, this event took place ca. 895. Its significance for the further history of the Pechenegs cannot be overestimated. This steppe people occupied an area that was a place of lively contacts - both commercial and cultural, but above all political between several countries, of which the most powerful were Byzantium and the Khazar Khaganate.

162 Cf. footnote 101 above.

163 Kristó 1996, 188. 